\title{
Cereal cultivation from the Iron Age to historical times: evidence from inland and coastal settlements in northernmost Fennoscandia
}

\author{
Torbjörn Josefsson ${ }^{1,2}$ (1) Greger Hörnberg ${ }^{2}$. \\ Lars Liedgren $^{2} \cdot$ Ingela Bergman $^{2}$
}

Received: 30 March 2016/Accepted: 16 August 2016/Published online: 2 September 2016

(c) The Author(s) 2016. This article is published with open access at Springerlink.com

\begin{abstract}
For several decades researchers have debated when cereal cultivation was introduced to northernmost Europe. Most previous studies have concentrated on sites along the coast or close to major rivers; these are areas well-suited to agriculture and represent routes for people and knowledge transfer, but omit other vast areas suitable for cultivation and sedentary settlement. Here, we present strong evidence of permanent cultivation from $\mathrm{AD}$ 480 onwards at a settlement located at the 64th parallel North in northern Sweden, currently situated $30 \mathrm{~km}$ inland from the Gulf of Bothnia. This predates the beginning of permanent cultivation at sites along the present coastline mentioned here and in results from previous studies of places at approximately the same latitude. Our results are based on continuous finds of cereal pollen grains at certain sites, selected on the basis of archaeological records, old maps, plus past and present elevations above sea level. We highlight the importance of taking factors into account such as access to waterways, communication routes and coast displacement following land uplift when choosing study sites in order to pinpoint early cultivation and sedentary settlements. We suggest that these results have implications for attempts to resolve the question of the history of early agriculture in other parts of northern Fennoscandia.
\end{abstract}

Communicated by M.-J. Gaillard.

Torbjörn Josefsson

torbjorn.josefsson@slu.se

1 Department of Forest Ecology and Management, Swedish University of Agricultural Sciences, 90183 Umeå, Sweden

2 The Institute for Subarctic Landscape Research, The Silver Museum, Torget, 93821 Arjeplog, Sweden
Keywords Agriculture · Cerealia · Land use history · Pollen analysis $\cdot$ Scandinavia $\cdot$ Shoreline displacement

\section{Introduction}

Attempts to detect the spread of cereal cultivation in northernmost Fennoscandia can be seen in the large number of pollen studies published over the last 40 years, reviewed by Josefsson et al. (2014). On the coastline of northern Norway, sedentary settlements with permanent cultivation of cereals started to appear during the Late Neolithic and Early Bronze Age (Johansen and Vorren 1986; Jensen and Elverland 2009). Evidence of early cultivation along the western shores of the Gulf of Bothnia is uncertain, but points to its establishment during the Late Bronze Age (Engelmark 1976; Tolonen 1972; Segerström 1990c; Viklund 2011), and from medieval times further north along its coastline (Segerström 1995; Hörnberg et al. 2014). However, most previous studies on this topic have been concentrated on sites along the coast or close to major rivers, which are areas well-suited to agriculture and along which people and knowledge could be transferred. Thus vast areas suitable for cultivation and for sedentary settlements have been omitted. Accordingly, an overall understanding of the spread and establishment of cereal cultivation in northernmost Fennoscandia is hampered by this uneven distribution of study sites. Surprisingly few studies have been carried out in the interior, where it has been presumed that permanent cultivation did not start until late medieval times (Segerström 1990b; Wallerström 1995; Hörnberg et al. 2015).

The earliest settlement history in this region is further obscured by the ever changing landscape, predominantly caused by postglacial isostatic land uplift in conjunction 
with changing coastlines (Bergman et al. 2003). In the western area, these processes are minor, but in some coastal parts of northernmost Sweden land uplift still amounts to nearly $1 \mathrm{~cm}$ annually (Ågren and Svensson 2007). This successive displacement of shorelines means that new areas suitable for agriculture and harvesting fodder for animals have emerged continuously during the Holocene. Accordingly, the oldest sedentary settlements are now to be found several kilometres inland from the coast or often a long way from the present shorelines of inland water bodies. Consequently, finding ways to identify the oldest sedentary settlements is a prerequisite for successfully identifying early cereal cultivation. Other key factors are the presence of undisturbed biological archives with preserved pollen, and archaeological artefacts related to agriculture (Jensen and Elverland 2009; Sköld et al. 2010). However, finding small and undisturbed mires or lakes in close proximity to the arable fields of sedentary settlements constitutes a major challenge, since many generations of land use have obscured the archaeological records (Ramqvist 2014) and disturbed the biological archives through peat collection, drainage or damming operations.

In this study, we analyse the land use history of four sedentary settlement sites which are mentioned in documents from the 16th century, to increase our knowledge of the beginning of cereal cultivation in northernmost Sweden. Two sites were chosen to represent supposedly early settlements in the coastal area, and two sites were supposedly later inland settlements located 30 and $80 \mathrm{~km}$ west of the present coastline, respectively. Our aims were to: (1) analyse and pinpoint the start of permanent cereal cultivation at each location, and (2) interpret and discuss temporal, spatial and methodological aspects of early cereal cultivation in northernmost Fennoscandia. We studied vegetation changes over the last 3,000 years, focusing on the period between 2,000 and 500 years before the present (вР), using analyses of pollen and charcoal fragments in stratigraphic records obtained from small mires and lakes. Old maps, in combination with archaeological field surveys, were used to locate the study sites. The period of time was chosen because it covers the earliest dates of cereal pollen types found in previous studies from this part of Sweden (Hörnberg et al. 2014, 2015; Segerström 1995). The archaeological time periods used in this paper are summarized in Table 1.

\section{Materials and methods}

The villages Tjärn and Svensbyn, which are located along the coast, and Norsjö and Burträsk, located in the interior, are all situated in the north-eastern part of boreal Sweden (Fig. 1). This region has a cold temperate climate, where
Table 1 Chronological table of archaeological time periods for Fennoscandia mentioned in the text

\begin{tabular}{ll}
\hline Archaeological period & Interval \\
\hline Mesolithic & $10000-4200 \mathrm{BC}$ \\
Neolithic & $4200-1700 \mathrm{BC}$ \\
Early Neolithic & $4200-3300 \mathrm{BC}$ \\
Middle Neolithic & $3300-2300 \mathrm{BC}$ \\
Late Neolithic & $2300-1700 \mathrm{BC}$ \\
Bronze Age & $1700-500 \mathrm{BC}$ \\
Early Bronze Age & $1700-1100 \mathrm{BC}$ \\
Late Bronze Age & $1100-500 \mathrm{BC}$ \\
Iron Age & $500 \mathrm{BC}-\mathrm{AD} 400$ \\
Pre-Roman Iron Age & $500 \mathrm{BC}-\mathrm{BC} / \mathrm{AD}$ \\
Early Roman Iron Age & $\mathrm{AD} 1-200$ \\
Late Roman Iron Age & $\mathrm{AD} 200-400$ \\
Migration Period & $\mathrm{AD} 400-550$ \\
Merovingian Period & $\mathrm{AD} 550-800$ \\
Viking Period & $\mathrm{AD} 800-1050$ \\
Medieval Period & $\mathrm{AD} 1050-1550$ \\
\hline
\end{tabular}

the mean temperature and precipitation for the period 1961-1990 varied between -12.4 and $-10.2^{\circ} \mathrm{C}$, and 40.2 and $38.1 \mathrm{~mm}$ in January, and 14.0 and $15.7^{\circ} \mathrm{C}$, and 80.0 and $57.1 \mathrm{~mm}$ in July, respectively (www.smhi.se). The landscape is affected by the postglacial rebound with a total land uplift of ca. $230 \mathrm{~m}$ during the Holocene (Lindén et al. 2006). The present uplift rate is ca. $0.8 \mathrm{~cm}$ per year ( $\AA$ gren and Svensson 2007) and has been quite constant during the last 5,000 years (Lindén et al. 2006). The coastal villages Tjärn and Svensbyn are located $75 \mathrm{~km}$ apart at elevations of 15 and $8 \mathrm{~m}$ a.s.l., and their sites rose above the sea about 1,900 and 1,000 years ago, respectively (Fig. 1). The bedrock is granitic and the soils mainly clay and silt at both places (www.sgu.se).

Norsjö and Burträsk are located 80 and $30 \mathrm{~km}$ inland from the coast, at elevations of 295 and $80 \mathrm{~m}$ a.s.l., respectively. Norsjö is located above the highest sea coastline whereas the Burträsk area emerged from the sea around 6,000 years ago (cf. Lindén et al. 2006). Today both villages are located close to the shores of lakes (Fig. 1). In Norsjö, the soils are dominated by moraines overlaying a mix of basaltic (gabbro and diorite) and quartz-rich sedimentary sandstone bedrock, and Burträsk is situated on glaciofluvial sediments and clay on granite and gneiss bedrock (www.sgu.se).

\section{Description of the study sites and sampling methods}

The village name Tjärn (meaning small lake or tarn) initially described a geographical feature, but over time it became the name of this village. It is located ca. $2 \mathrm{~km}$ 
Fig. 1 Map of Fennoscandia with the study area indicated by a rectangle. Overview map with the locations of the four study sites (stars), place names and major rivers and lakes mentioned in the text. Detailed maps with the exact positions of the four study sites (stars) as well as major features of the physical geography and $10 \mathrm{~m}$ contour. Scale of detailed maps is $1: 100,000$

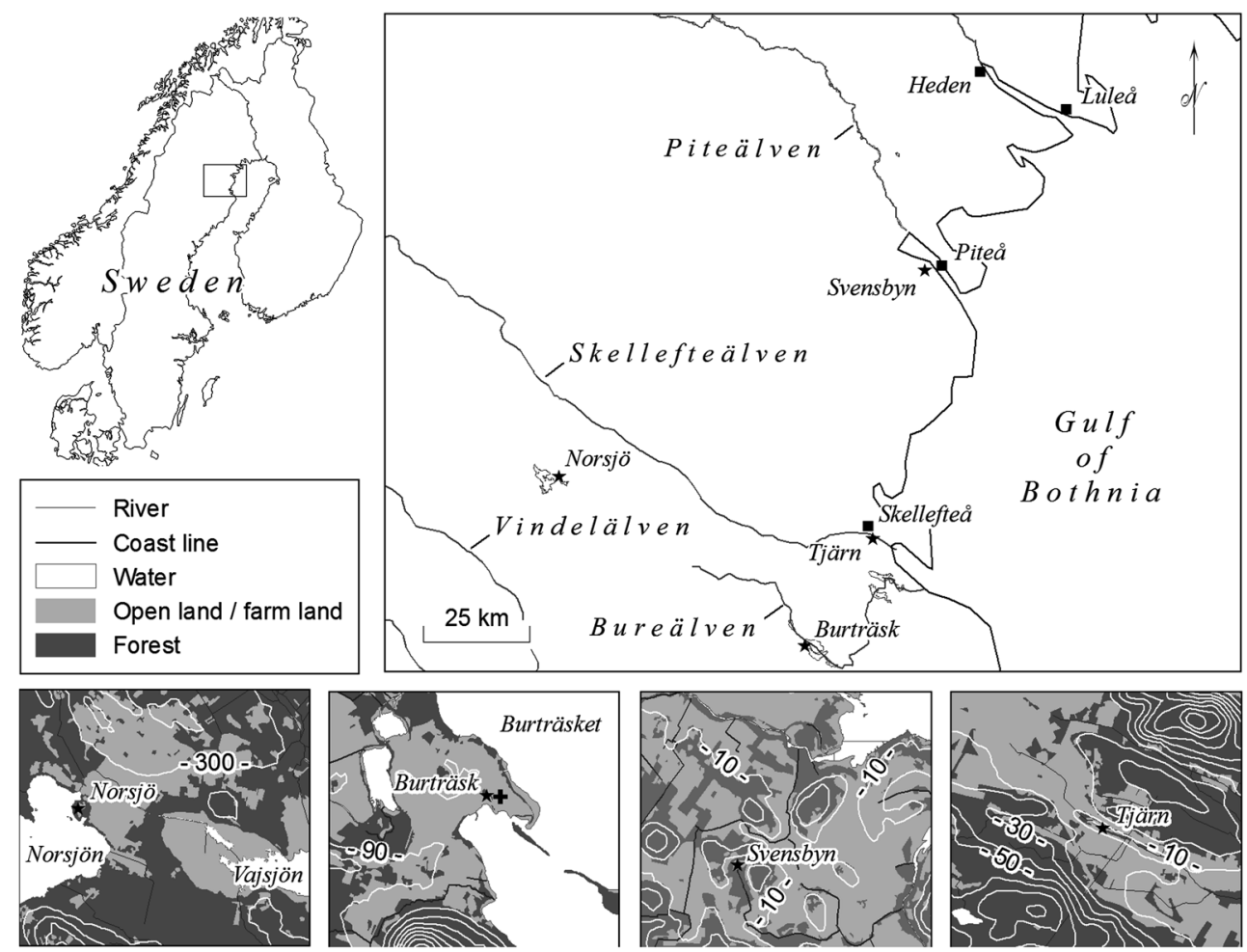

south of the Skellefteälven, a river on the southern boundary of the town of Skellefteå. During the Bronze Age this area was a bay close to the river mouth, and several traces of burial sites, today at 25-35 $\mathrm{m}$ a.s.l., show that this area was already being used at this time (www.fmis.raa.se). The medieval farms were established on a ridge just north of the depression in which a lake, Tjärn, is located (Fig. 1). In $\mathrm{AD} 1543$, there were three farms situated here (Nordlander 1905). The small lake was isolated from the sea between ca. AD 880 and 950 based on real time kinematic levelling (RTK) of the lake outlet level at $8.5 \mathrm{~m}$ a.s.l. and a land uplift rate of 7.5-8 mm per year (Ågren and Svensson 2007). Tjärn is marked on a map of property boundaries from AD 1648, when the lake was surrounded by farmland (Fig. 2a). Samples for pollen analysis and radiocarbon dating were collected from a swamp wood $\left(64^{\circ} 43^{\prime} 32^{\prime \prime} \mathrm{N}\right.$, $\left.20^{\circ} 59^{\prime} 14^{\prime \prime} \mathrm{E}\right)$ ca. $35 \times 70 \mathrm{~m}$ in size and located just west of the lake and surrounded by arable fields. The vegetation is characterized by Betula pubescens (downy birch) and Alnus incana (grey alder), Salix shrubs, and by Filipendula ulmaria, Calamagrostis spp., Deschampsia caespitosa, Phleum pratense and Carex spp. in the field layer. Five overlapping cores covering the top $10-150 \mathrm{~cm}$ were collected in June 2012 using a Russian peat corer. The cores were wrapped in plastic and aluminium foil and stored in freezers in the laboratory. The top $97 \mathrm{~cm}$ consisted of low
Fig. 2 Excerpts of historical maps showing a Tjärn surrounded by farm land in $\mathrm{AD}$ 1648 , b Hamptjärn close to the Svensbyn village in AD 1700 , c Norsjö with the small peninsula and settlements in $\mathrm{AD}$ 1703, d Burträsk and the small lake located in a cleared area close to three farms in $\mathrm{AD} 1686$. Pollen sampling sites marked with stars. Source www. lantmateriet.se
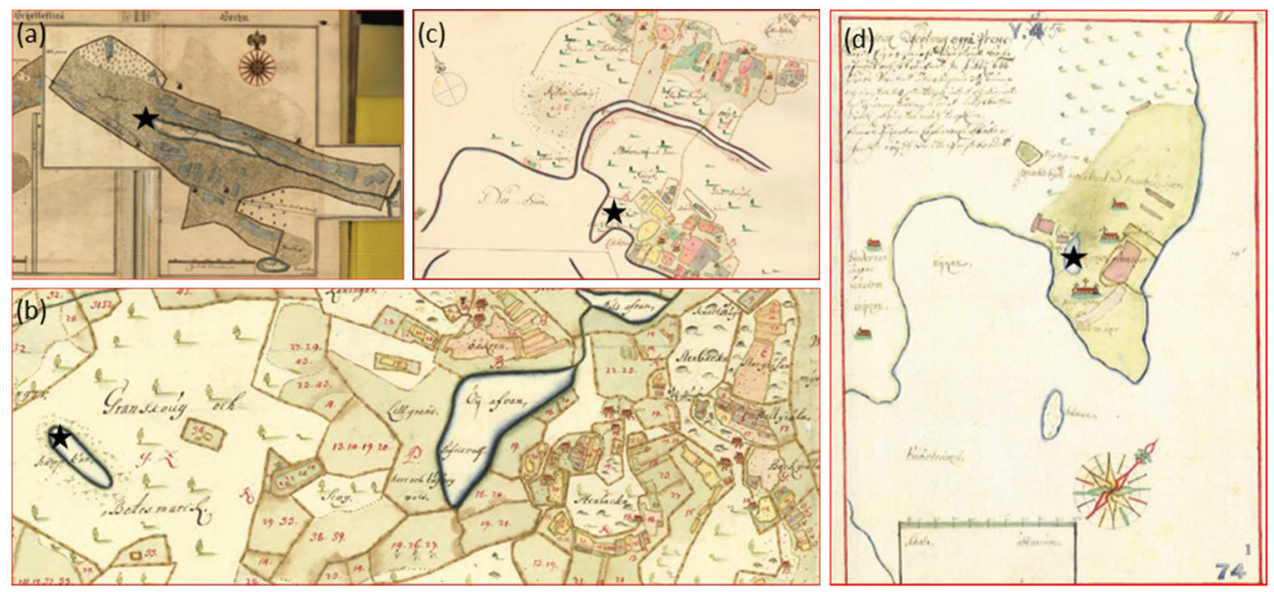
to intermediately decomposed Sphagnum peat with mineral sediments further down. In total, four samples for radiocarbon dating and 32 samples for pollen and charcoal analysis were collected from the cores at depths between 31 and $65 \mathrm{~cm}$.

Svensbyn (Sven's village) is an Old Norse male name characteristic of villages with permanent cultivation which were established along the coast during the 14th century or even earlier. Later, new settlements were established in cleared areas at the edges of the villages and they often have place names ending with "-mark" (land), for example Arnemark (Hörnberg et al. 2014). During the 16th century Svensbyn was the largest village in Pitea parish, with 24 farms in AD 1543 (Nordlander 1905) and 22 farms mentioned in "Älvsborgs lösen" of 1571. This denotes the ransom that Sweden had to pay Denmark to recover Älvsborg castle after a war between Sweden and Denmark (www.riksarkivet.se). These farms were situated over a $3 \times 2 \mathrm{~km}$ area along the shore of a former inlet from the sea. In the central part of this village no biological archive was found due to agricultural activities, drainage ditches, roads and structures. However, on a map of property boundaries dated to AD 1700, a small lake was marked ca. $1.5 \mathrm{~km}$ west of the central part of the village (Fig. 2b). The name of this small lake, Hamptjärn (hemp lake), indicates that it was used for retting hemp during this time or in the past. Initially, it was isolated from the sea around 200 BC but due to paludification the lake has turned into a mire. Today, the mire is $90 \times 50 \mathrm{~m}$ in size, located at $17 \mathrm{~m}$ a.s.l. and surrounded by a small wood and arable land (Fig. 1). Samples were collected from the north-eastern part of the mire in March $2009\left(65^{\circ} 19^{\prime} 19^{\prime \prime} \mathrm{N}, 21^{\circ} 12^{\prime} 31^{\prime \prime} \mathrm{E}\right)$. The small wood that surrounds the mire is dominated by Alnus incana, Pinus sylvestris (Scots pine) and Picea abies (Norway spruce) trees, and the ground vegetation is characterized by Carex spp. and Sphagnum spp. The top $50 \mathrm{~cm}$ of the organic material contained too much water and was not sampled. Peat cores were therefore collected from $50 \mathrm{~cm}$ down to $150 \mathrm{~cm}$. In total, four samples for radiocarbon dating and 32 samples for pollen and charcoal analysis were collected from cores between 70 and $109 \mathrm{~cm}$ deep.

The village of Norsjö is located on the north-east side of Norsjön (Fig. 1). The prefix "Nor-" indicates something "narrow", probably referring to the constricted water passage (Noret) between two lakes, Norsjön and Vajsjön. According to a map of property boundaries dated to $\mathrm{AD}$ 1703 , the village was situated on both sides of this narrow passage (Fig. 2c). Archaeological finds indicate that this area was frequently used from the Neolithic to the end of the Bronze Age. In addition, two finds of strike-a-light stones could indicate burial or settlement sites in this area during the Migration Period (www.fmis.raa.se). Five farms were registered here in the taxation book from AD 1543
(Nordlander 1905) and the same in AD 1571 (www.riksar kivet.se). A small swamp wood at $291 \mathrm{~m}$ a.s.l., situated between this peninsula and the southern part of the village, was used for sampling. The wood is dominated by Betula pubescens, Sorbus aucuparia (rowan) and Pinus sylvestris, the field layer by dwarf shrubs (Vaccinium myrtillus and $V$. uliginosum), Rubus chamaemorus, Melampyrum pratense and Epilobium angustifolium, and the woodland floor is covered by Sphagnum girgensohnii. Two peat cores, covering 1 to $100 \mathrm{~cm}$, were collected in August 2012 $\left(64^{\circ} 54^{\prime} 25^{\prime \prime} \mathrm{N}, 19^{\circ} 28^{\prime} 05^{\prime \prime} \mathrm{E}\right)$. In total, eight samples for radiocarbon dating and 44 samples for pollen and charcoal analysis were collected from the cores at depths between 10 and $70 \mathrm{~cm}$.

The village of Burträsk is located on a peninsula on the western side of a lake, Burträsket (Fig. 1). The prefix "Bur" in this case probably indicates some kind of storage building. There are a number of prehistoric sites in the surroundings of Burträsket dating back to ca. 2000 BC and possibly even earlier (Broadbent 1982, www.fmi.raa.se). In AD 1543 and 1571 the village of Burträsk had 22 and 27 farms, respectively (Nordlander 1905, www.riksarkivet.se). A small lake located in the centre of an open area and close to a church is shown on a property map dated to 1686 (Fig. 2d). The 1st church was probably erected here in the late 16th century. Today, this $90 \mathrm{~m}$ long and $30 \mathrm{~m}$ wide lake is located at $79 \mathrm{~m}$ a.s.l. in an urban environment just south of the church. Around the lake there are a few downy birch trees in a park-like environment including grassdominated lawns. From its deepest point (at $1.8 \mathrm{~m}$; $64^{\circ} 31^{\prime} 08^{\prime \prime} \mathrm{N}, 20^{\circ} 39^{\prime} 47^{\prime \prime} \mathrm{E}$ ) we collected four sediment cores covering 10-210 cm in March 2012 (Fig. 1). Highly decomposed organic material covered the $10-180 \mathrm{~cm}$ part of the core and minerogenic material the $180-210 \mathrm{~cm}$ part. In total, ten samples for radiocarbon dating were analysed, of which six showed a reversed stratigraphy down to $128 \mathrm{~cm}$, indicating that material had been dumped into the lake, influencing the stratigraphy higher up (see results). The lower part of the sediment, from $129 \mathrm{~cm}$ and further down, was undisturbed. Based on the four remaining radiocarbon dates, 24 samples for pollen and charcoal analysis were collected from the cores at depths between 129 and $160 \mathrm{~cm}$.

\section{Sample preparation, radiocarbon dating and pollen analysis}

Fragments of Sphagnum have been shown to give reliable accelerator mass spectrometry (AMS) dates (Nilsson et al. 2001). Accordingly, we extracted stems and leaves of Sphagnum and also seeds and leaves of other plants amounting to a minimum of $5 \mathrm{mg}$ dry weight per sample. In six cases, however, bulk peat samples were used. In all, 
26 samples were sent to the Angström Laboratory in Uppsala for AMS dating (Table 2). Dates were calibrated using the IntCal13 calibration curve (Reimer et al. 2013) and age-depth models for each site were constructed using the non-Bayesian Clam model package (Blaauw 2010) and the statistical software package R (R Development-CoreTeam 2013). Clam calculates the weighted "best" mean of all sampled calendar years for every depth, including an estimate of the $95 \%$ confidence interval (Blaauw 2010). Unless specified otherwise, dates are expressed as calibrated years $\mathrm{BC} / \mathrm{AD}$.

Based on the radiocarbon dates, $1 \mathrm{~cm}^{3}$ samples for pollen and charcoal analysis were collected using a scalpel. The samples were treated with $\mathrm{KOH}$ to dissolve organic material and they were then treated by acetolysis and finally mounted in safranin-stained glycerine. All samples were analysed for pollen, spores and charcoal particles
$>50 \mu \mathrm{m}$. A minimum of 500 terrestrial pollen grains excluding spores were counted at each level. For identification, keys by Moore et al. (1991) and descriptions in the PalDat database (www.paldat.org) were used together with a reference pollen collection from INSARC, including pollen of old cereal types (Hörnberg et al. 2014). Pollen types which were only recorded once were omitted from the pollen percentage diagrams. The pollen percentage diagrams were constructed using the TILIA and TILIA.GRAPH programs (Grimm 1991, 2004). We also performed a comparison of the pollen data obtained from the study sites, including percentages of pollen from trees, cereal pollen types, apophytes (pollen of native plants favoured by human activities) and anthropochores (pollen of cultivated crops and introduced non-native plants), and other herbs. A consolidated pollen diagram was constructed using OriginPro 2015.
Table 2 Radiocarbon ages of peat and bulk samples from the four study sites processed at the Ångström Laboratory in Uppsala, Sweden and calibrated using the IntCal 13 calibration curve (Reimer et al. 2013)

\begin{tabular}{|c|c|c|c|c|}
\hline Site, Lab.code & Level $(\mathrm{cm})$ & Material & ${ }^{14} \mathrm{C}$ age & cal Age $(2 \sigma)$ \\
\hline \multicolumn{5}{|l|}{ Tjärn } \\
\hline Ua-46671 & $31-32$ & Mosses, seeds & $198 \pm 30$ & AD 1648-1954 \\
\hline $\mathrm{Ua}-47252$ & $40-41$ & Mosses, seeds, needles & $280 \pm 34$ & AD 1493-1796 \\
\hline $\mathrm{Ua}-47253$ & $50-51$ & Mosses, seeds, needles & $541 \pm 38$ & AD 1310-1439 \\
\hline $\mathrm{Ua}-46672$ & $59-60$ & Bulk & $1,273 \pm 38$ & AD $661-863$ \\
\hline \multicolumn{5}{|l|}{ Svensbyn } \\
\hline $\mathrm{Ua}-47160$ & 89-90 & Mosses & $1,064 \pm 37$ & AD 894-1024 \\
\hline Ua-47161 & $99-100$ & Mosses, seeds & $1,541 \pm 34$ & AD $426-589$ \\
\hline Ua-39160 & $105-106$ & Mosses & $1,420 \pm 30$ & AD 583-660* \\
\hline Ua-47162 & $109-110$ & Bulk & $2,098 \pm 45$ & 347 BC-AD 2 \\
\hline \multicolumn{5}{|l|}{ Norsjö } \\
\hline Ua-47249 & $15-16$ & Mosses & $220 \pm 32$ & AD 1641-1954 \\
\hline Ua-44927 & $20-21$ & Mosses & $686 \pm 31$ & AD 1267-1388 \\
\hline $\mathrm{Ua}-44928$ & $30-31$ & Mosses & $1,166 \pm 32$ & AD 772-966 \\
\hline $\mathrm{Ua}-47250$ & $35-36$ & Mosses & $1,498 \pm 36$ & $\mathrm{AD} 430-650^{*}$ \\
\hline Ua-44273 & $39-40$ & Mosses & $1,483 \pm 32$ & $\mathrm{AD} 440-647$ \\
\hline Ua-47251 & $45-46$ & Mosses & $1,711 \pm 34$ & AD 249-398 \\
\hline Ua-44929 & $50-51$ & Mosses, seeds & $1,427 \pm 30$ & $\mathrm{AD} 570-660^{*}$ \\
\hline Ua-44274 & $70-71$ & Bulk & $2,034 \pm 31$ & 157 вC-AD 50 \\
\hline \multicolumn{5}{|l|}{ Burträsk } \\
\hline Ua-46668 & $50-51$ & Bulk & $1,702 \pm 47$ & $\mathrm{AD} 220-440 *$ \\
\hline Ua-46669 & $74-75$ & Bulk & $1,499 \pm 52$ & $\mathrm{AD} 430-650 *$ \\
\hline Ua-46670 & $100-101$ & Bulk & $1,014 \pm 30$ & $\mathrm{AD} 970-1150 *$ \\
\hline Ua-48230 & $120-121$ & Mosses & $862 \pm 31$ & $\mathrm{AD} 1040-1260 *$ \\
\hline Ua-48231 & $125-126$ & Mosses, bark & $1,513 \pm 32$ & $\mathrm{AD} 430-630 *$ \\
\hline $\mathrm{Ua}-48232$ & $128-129$ & Mosses, seeds, leaves & $848 \pm 30$ & AD $1050-1270 *$ \\
\hline Ua-47365 & $131-132$ & Mosses, needles, leaves & $837 \pm 34$ & $\mathrm{AD} 1058-1265$ \\
\hline Ua-48233 & $140-141$ & Mosses, seeds, leaves & $1,582 \pm 30$ & AD 411-544 \\
\hline Ua-47366 & $160-161$ & Mosses, seeds, needles & $2,757 \pm 36$ & $993-826$ вс \\
\hline Ua-47367 & $186-187$ & Mosses, seeds, needles & $4,717 \pm 41$ & $3632-3373$ вс \\
\hline
\end{tabular}

* Date was considered to be an outlier and not used in the construction of the age-depth models 
All diagrams were divided into pollen assemblage zones (PAZ) based on land use history and the following assumptions: PAZ I-pre-agrarian conditions with no cereal pollen types, low percentages of grass and apophytes and other herbs, stable and high percentages of trees; PAZ II-shifting cultivation with finds of cereal pollen types, grass occurring more or less continuously, low or increasing percentages of apophytes and other herbs, tree percentages stable or decreasing; PAZ III-permanent cereal cultivation with cereal pollen occurring continuously, grass and apophytes and grass percentages increasing. Shifting cultivation in northern Fennoscandia commonly involved slash-and-burn cultivation of Secale (rye) (Hicks 1988).

\section{Results}

\section{Radiocarbon dating and chronology}

Nine dates in total, of which six were from Burträsk, were omitted and not used in the age-depth models, mainly due to mixing of material in the peat profiles (Table 2). Two omitted dates from Svensbyn (105 cm depth) and Norsjö (50 cm depth) were considered to be too young in comparison to the other dates, possibly due to penetration by fine roots, and one date from Norsjö (35 cm depth) was considered to be too old, possibly due to inflow of older material. The six omitted dates from Burträsk (50-128 cm depth) all indicated that material had been dumped into the little lake because older material was overlaying younger material. The remaining dates were used to construct interpolated age-depth models for each site (Fig. 3). Because all dates used, except for three bulk samples, were based on macrofossils of terrestrial plants, the influence of the "freshwater reservoir effect" (Philippsen 2013) was considered to be minimal. In Tjärn, all dates were used for the age-depth model, while in Svensbyn and Norsjö one and two dates, respectively, were rejected (Table 2). The two topmost ${ }^{14} \mathrm{C}$ dates at Tjärn $(198 \pm 30$ at $31-32 \mathrm{~cm}$, and $280 \pm 34$ at $40-41 \mathrm{~cm}$ ) are not statistically different ( $t$ test, $95 \%$ ), indicating a rapid accumulation rate in that part of the profile. In Svensbyn and Burträsk, the age models showed a rather continuous accumulation rate for the sequences of the stratigraphy that were analysed, and the Norsjö age-depth model indicated a reduced accumulation rate higher up in the stratigraphy, except for the top $10 \mathrm{~cm}$ (Fig. 3). However, because no radiocarbon dating was carried out above $90 \mathrm{~cm}$ depth in Svensbyn, the accumulation rate from $90 \mathrm{~cm}$ and upwards may be skewed. We therefore present an alternative age-depth model where we assume the same accumulation rate between 90 and $70 \mathrm{~cm}$ as between $100 \mathrm{~cm}$ and $90 \mathrm{~cm}$.

\section{Vegetation history of the study sites}

Results of the pollen analyses from Tjärn, Svensbyn, Norsjö and Burträsk are presented in Figs. 4, 5, 6 and 7, and major changes in pollen percentages are summarized in Tables 3 and 4 . The comparison of the pollen data obtained from the study sites is presented in Fig. 8.

\section{Tjärn}

During PAZ TJ I (AD 300-950), when the small lake was part of a shallow bay and still connected to the sea, the pollen percentages of trees are continuously high and those of herbs, grasses and sedges low (Table 3; Figs. 4, 8). The first signs of land use that included cereal cultivation ( $\mathrm{Se}$ cale cereale and Cerealia undiff.) appear in PAZ TJ II from around AD 950, when the small lake became isolated from the sea, and shortly thereafter there are increased percentages of apophytes; noteworthy are Artemisia, Rumex and Melampyrum. In addition, the amount of charred particles increases somewhat. During PAZ TJ III (AD 1170-1780) the pollen percentage of trees decreases steadily, several cereal pollen types, Hordeum, Secale and Triticum, occur continuously and the proportions of apophytes (grasses, Apiaceae, Artemisia, Cannabis-type and Rumex-type) and other herbs increase. Pollen of Chenopodiaceae appears sporadically. From around AD 1480 Linum usitatissimum pollen is recorded, and from AD 1610 the proportion of Cannabis-type pollen starts increasing and subsequently reaches over $20 \%$. Charred particles occur continuously throughout this period.

\section{Svensbyn}

During PAZ SV IIa (125 BC to AD 1060) the percentage of tree pollen is high (90-94\%) with Picea pollen steadily increasing and Alnus and Betula pollen decreasing (Table 3; Figs. 5, 8). Hordeum-type pollen is recorded intermittently from $\mathrm{AD} 125$ onwards. The proportion of grasses decreases from 10 to $2 \%$, but grass pollen $>40 \mu \mathrm{m}$ and pollen from sedges are both recorded continuously. Human land use is indicated throughout the period by intermittent records of the following pollen types, Artemisia, Cannabis, Filipendula, Juniperus, Rumex and Urtica, with single finds of Caryophyllaceae, Chenopodiaceae and Epilobium, all adding up to a high proportion of apophytes with a peak around AD 100. During PAZ SV IIb (AD 1060-1180), the first appearance of Secale cereale pollen is recorded around $\mathrm{AD} 1060$ (AD 990-1110, 2 $\sigma$ ). Land use during this PAZ is indicated by increasing percentages of grass pollen and Cannabis-type pollen, as well as the presence of several apophytes including Artemisia, Caryophyllaceae, Chenopodiaceae, Epilobium, Rumex, 
(a)

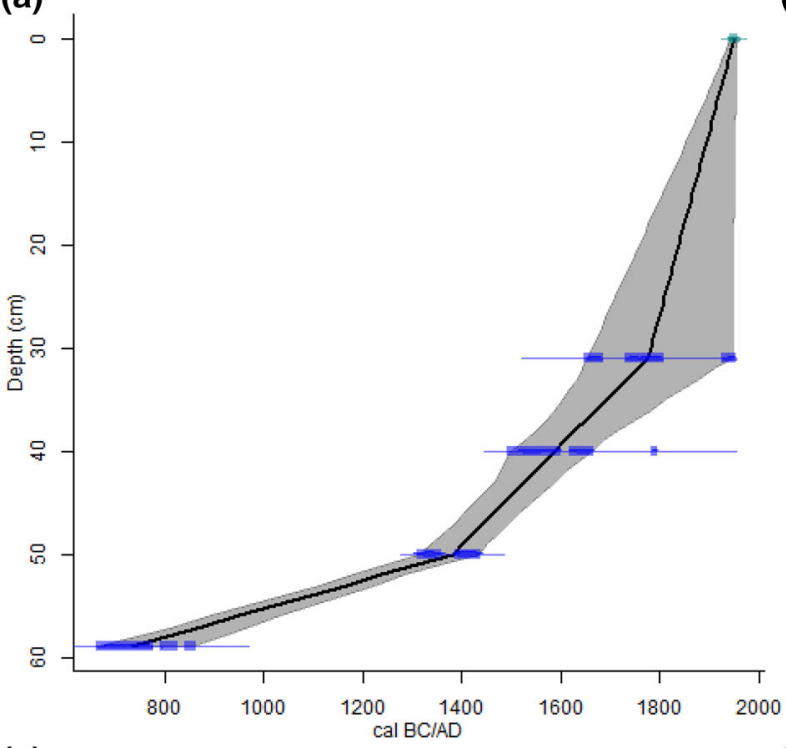

(c)

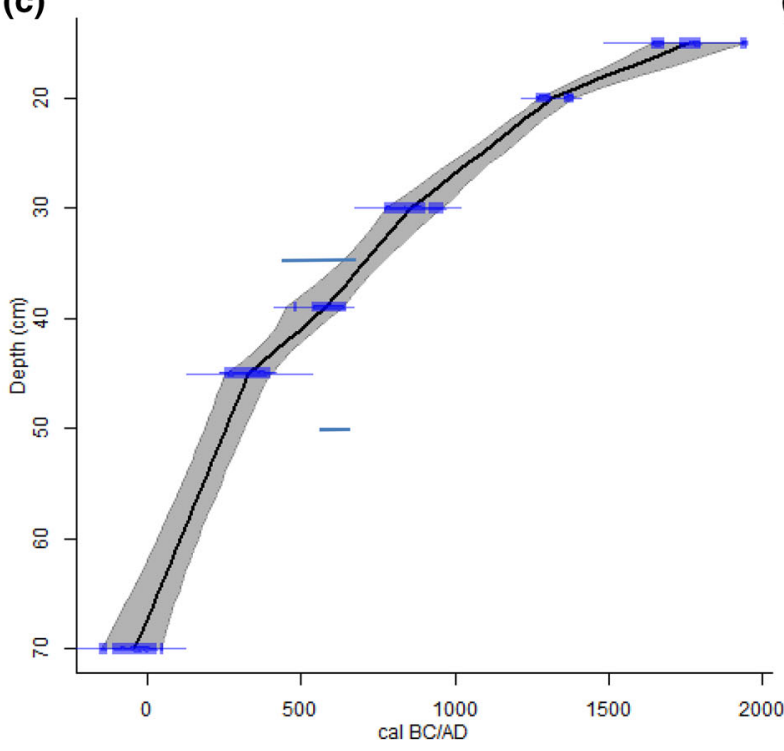

Fig. 3 Age-depth models (BC/AD) for the peat stratigraphy at a Tjärn, b Svensbyn, c Norsjö, d Burträsk. Shaded areas show the $95 \%$ confidence intervals of the model (Blaauw 2010). An alternative age-

Plantago major and Urtica (Table 3; Figs. 5, 8). However, according to the alternative age-depth model (between 90 and $70 \mathrm{~cm}$ depth, dashed line in Fig. 3, dates within brackets in Fig. 5), the recorded Secale pollen would date to $\mathrm{AD} 1340$ (AD 1270-1390). Consequently, the age of the first Secale pollen is most certainly somewhere in between AD 1060 and 1340 (AD 990-1390, 2 $\sigma$ ).

\section{Norsjö}

During PAZ NO I (40 BC to AD 500) the percentages of tree pollen are high (Table 4; Figs. 6, 8). The pollen values for shrubs, grasses and herbs are low and only a few pollen types (b)

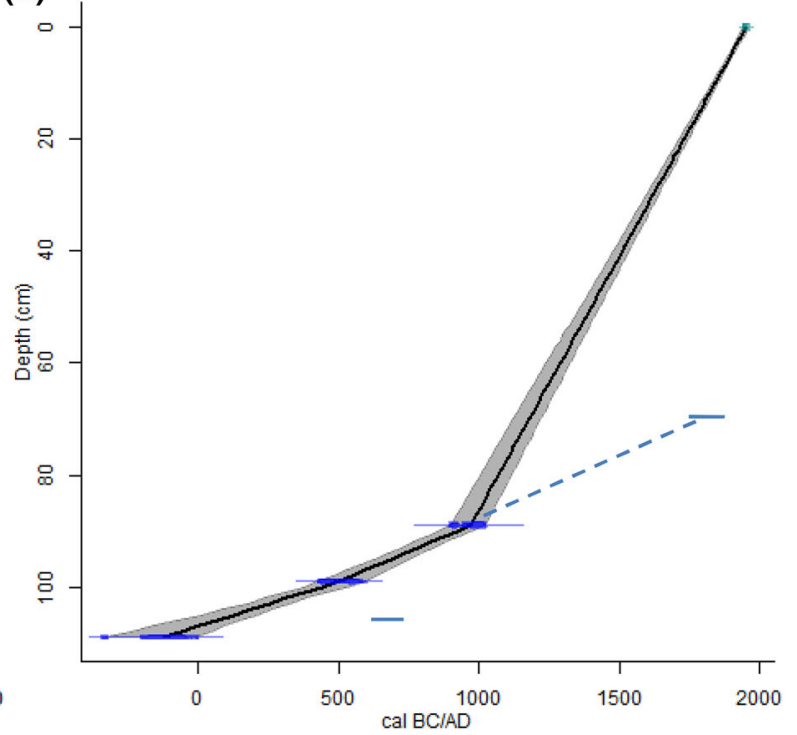

(d)

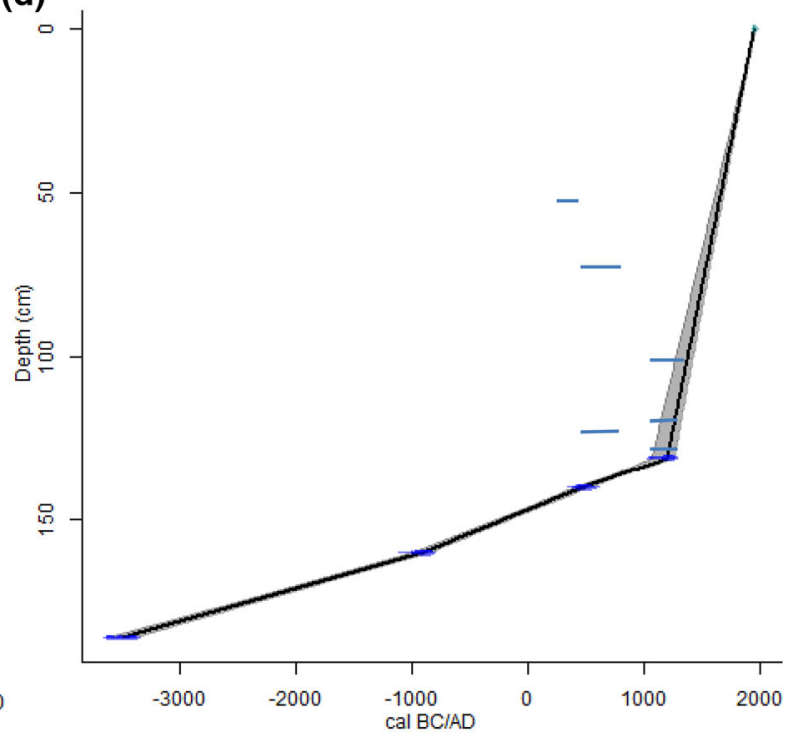

depth model is given for Svensbyn between 70 and $90 \mathrm{~cm}$ (dotted line), based on the same accumulation rate as the one between 90 and $100 \mathrm{~cm}$. Omitted dates are shown as ranges

of apophytes (Artemisia, Cannabis, Cichoriaceae, Rumex and Urtica) occur at low levels. The percentage of other herbs is low but increases temporarily around AD 400. The percentage of Sphagnum spores is initially high (20\%) but slowly decreases and charred particles occur continuously at low levels throughout this period. During PAZ NO II (AD 500-1490), Betula pollen increases initially until AD 650 and then the percentage of total tree pollen starts decreasing (Table 4; Figs. 6, 8). From AD 500 to 1490 signs of land use are subtle and include the first appearances of Secale pollen at $\mathrm{AD} 500$ and 760, Hordeum-type pollen at $\mathrm{AD} 1270$, and recurrent finds of grass pollen $>40 \mu \mathrm{m}$ and pollen of Artemisia, Cannabis-type, Melampyrum and Urtica-type. During 


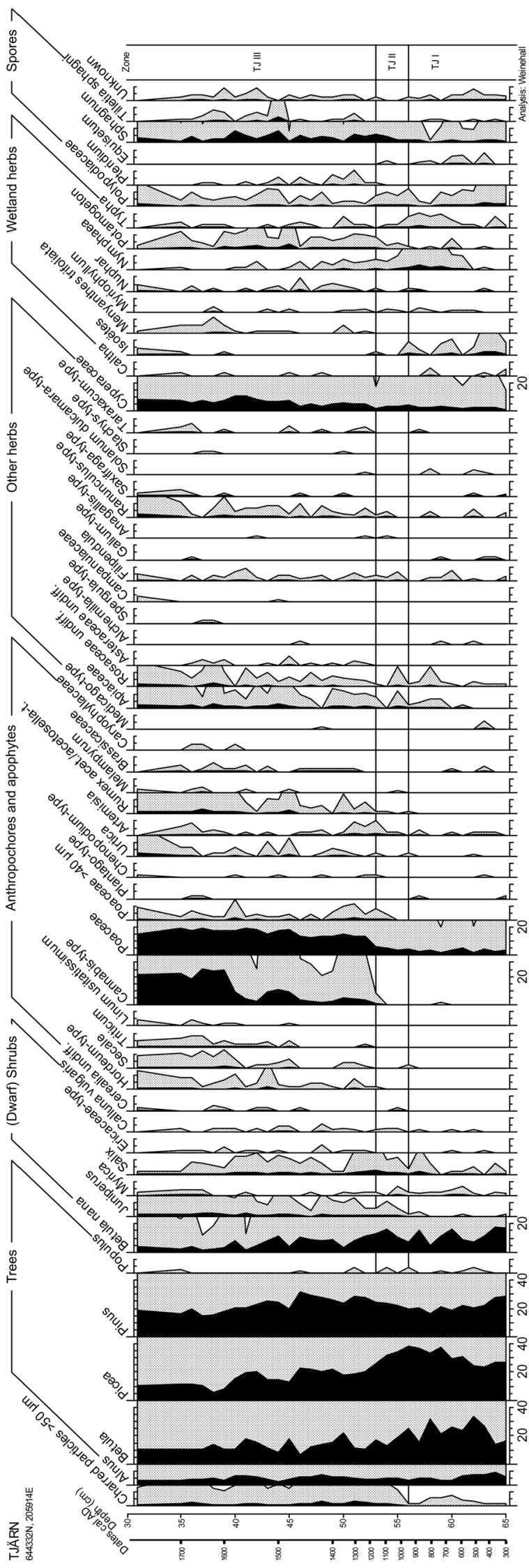

Fig. 4 Pollen percentage diagram for Tjärn divided into three pollen assemblage zones. From left to right: interpolated calibrated ages (AD); depths (cm); microscopic charred particles $(>50 \mu \mathrm{m})$; pollen and spore types as percentages (black shading) and at $\times 10$ magnification (grey shading). The solid lines mark zones: TJ I preagrarian conditions, TJ II shifting cultivation, TJ III permanent cultivation. Herb pollen types only recorded once and at one level have been omitted

this period there are also single appearances of Chenopodiaceae and Brassicaceae pollen, but the overall percentage of apophytes and other herbs is consistently low. Between AD 750 and 1200 the proportion of charred particles varies greatly with a peak around 800 . During this time the percentage of tree pollen fluctuates at low levels, the percentage of Ericaceae pollen increases temporarily, peaking at $32 \%$ around $\mathrm{AD} 1050$, and Epilobium-type pollen occurs intermittently.

From AD 1490 until the present (PAZ NO III), pollen of the cereals Secale, Triticum and Hordeum-type occurs and apophytes (predominately grasses and Rumex, but also Artemisia, Cannabis-type, Caryophyllaceae, Chenopodiaceae, Cichoriaceae, Epilobium-type, Melampyrum and Urtica) increase (Table 4; Figs. 6,8). At the same time the proportion of tree and shrub pollen decreases. Charred particles occur continuously at low levels throughout this period.

\section{Burträsk}

High percentages $(91-95 \%)$ of tree pollen characterize PAZ BU I (900-560 вс) (Table 4; Figs. 7, 8). During this time period the following pollen types occur: Alnus, Salix, Cannabis, Ranunculus and Cyperaceae. Charred particles occur at low levels. The first signs of land use that included cereal cultivation, with records of Secale cereale and Hordeum-type, appear around 560 BC. At this date Salix, Juniperus, large grasses, grasses, Artemisia, Cannabis-type and Urtica are also recorded. The total percentage of tree pollen remains high (89-92\%) during PAZ BU II (550 BC to $\mathrm{AD} 480$ ). During this period Secale, Poaceae $>40 \mu \mathrm{m}$ and Melampyrum are recorded intermittently, Poaceae continuously, and Cannabis-type, Chenopodiaceae, Plantago lanceolata and Rumex sporadically. The proportion of charred particles increases around $150 \mathrm{BC}$ and $\mathrm{AD} 70$. During PAZ BU III (AD 480-1210), the percentages of Alnus, Betula and Pinus pollen decrease, while the percentage of Picea pollen increases. Overall, the total proportion of tree pollen decreases. Between AD 480-640 Secale pollen is recorded continuously and Hordeum-type pollen once. The first appearance of Triticum-type pollen is dated to $\mathrm{AD} 880$, and from $\mathrm{AD} 800$ onwards cereal pollen is recorded in every level except one, at $130 \mathrm{~cm}$ depth corresponding to AD 1210. During this period the percentages 


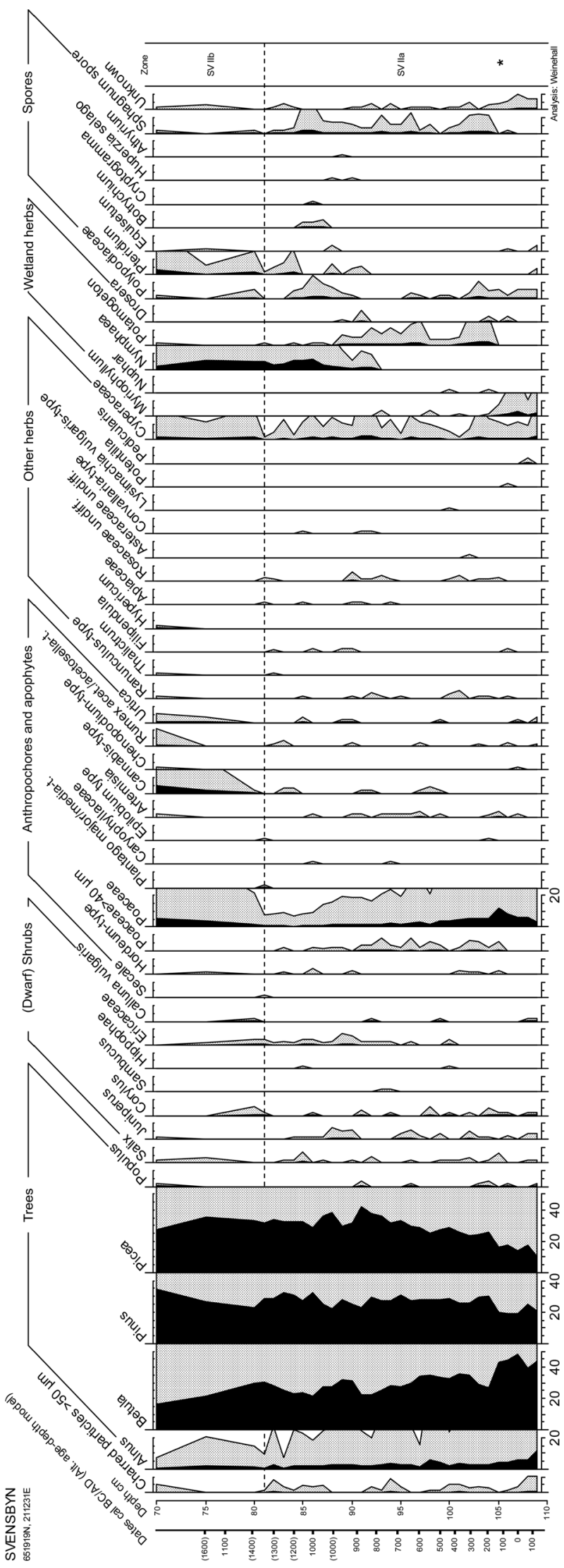

4Fig. 5 Pollen percentage diagram for Svensbyn divided into two pollen assemblage sub-zones. From left to right: interpolated calibrated ages and calibrated ages from alternative age-depth model between 75 and $90 \mathrm{~cm}$ within brackets (BC/AD); depths $(\mathrm{cm})$; microscopic charred particles $(>50 \mu \mathrm{m})$; pollen and spore types as percentages (black shading) and at $\times 10$ magnification (grey shading). The dotted line marks sub-zones: SV IIa possible shifting cultivation where asterisk indicates the first recorded Hordeum-type pollen; SV $I I b$ shifting cultivation. Herb pollen types only recorded once and at one level have been omitted

of Juniperus, grass and Cannabis-type pollen increase, and pollen of Apiaceae, Artemisia, Asteraceae, Brassicaceae, Caryophyllaceae, Chenopodiaceae, and Urtica-type are recorded occasionally. Pollen of Rumex-type occurs continuously. Charred particles occur continuously at low levels and pollen of Epilobium-type is recorded once at ca. AD 1200.

\section{Discussion}

The question of when cereal cultivation was introduced into northernmost Europe has been debated in many publications. Most indications of early agriculture in this region are based on isolated finds of cereal pollen grains (Josefsson et al. 2014). As pointed out by Behre (2007) and Lahtinen and Rowley-Conwy (2013) for example, such finds cannot be taken as evidence of early cultivation without the support of more comprehensive pollen data, including synchronous finds of scattered cereal pollen types at several sites, continuous finds of cereal pollen grains, macrofossils or archaeological data. Recently, however, charred cereal grains that verify Late Bronze Age cultivation have been found in parts of northern Sweden (Viklund 2011; Lindqvist and Granholm 2016) and in northernmost Norway (Sjögren and Arntzen 2013), which are regions where cultivation has previously only been indicated by single or scattered pollen records (Tolonen 1972; Engelmark 1976; Vorren and Alm 1985; Sjögren 2010).

In this study, we present strong indications of permanent cultivation as early as $\mathrm{AD} 480$ at a settlement that today is situated $30 \mathrm{~km}$ inland from the shore of the Gulf of Bothnia. This date precedes the start of permanent cultivation at sites situated along the present coast as shown in this study and in previous studies from about the same latitude (Engelmark 1976; Segerström 1990a). Our results are based on certain pollen assemblages including continuous finds of cereal pollen grains at sites selected on the basis of information on old property maps and past and present elevations above sea level. Below we discuss our findings from an ecological and archaeological point of view and compare our results with previous studies from 


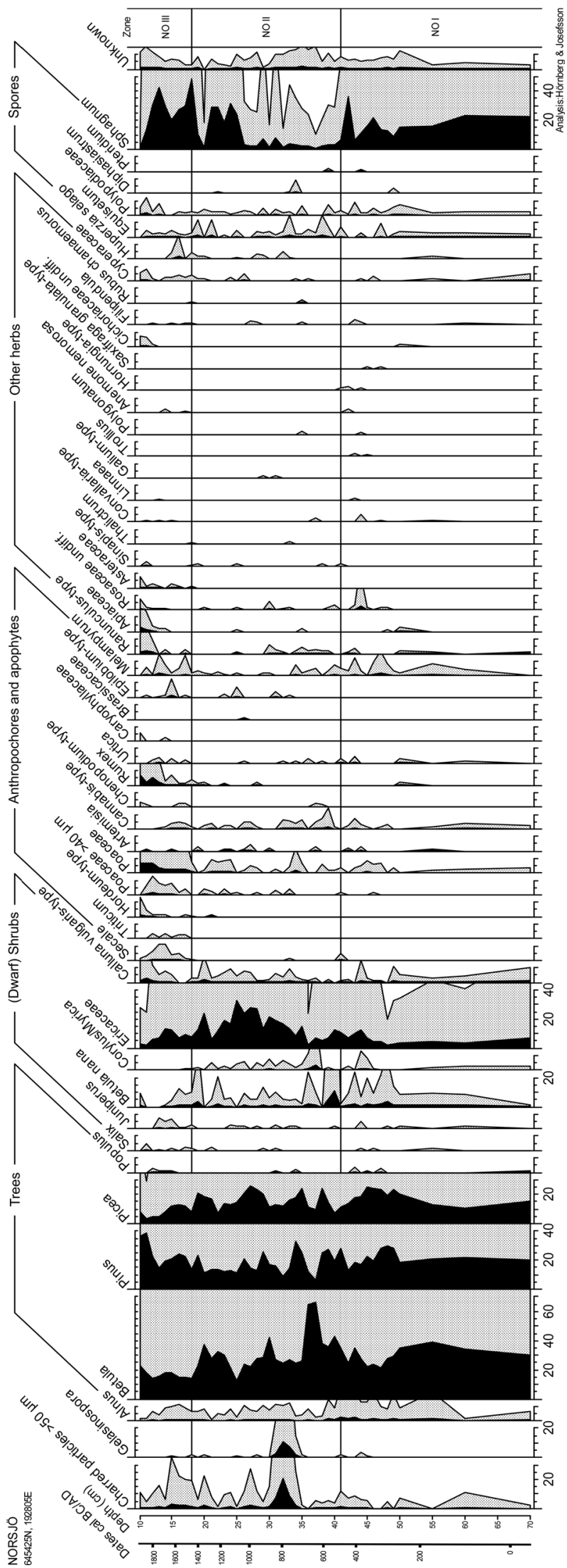

4Fig. 6 Pollen percentage diagram for Norsjö divided into three pollen assemblage zones. From left to right: interpolated calibrated ages $(\mathrm{BC} / \mathrm{AD})$; depths $(\mathrm{cm})$; microscopic charred particles $(>25 \mu \mathrm{m})$; pollen and spore types as percentages (black shading) and at $\times 10$ magnification (grey shading). The solid lines mark zones: NO I preagrarian conditions, NO II shifting cultivation, NO III permanent cultivation. Herb pollen types only recorded once and at one level have been omitted

northern Fennoscandia. We also discuss our methodological approach and factors such as access to waterways and shore displacement following land uplift and their role when choosing study sites in order to pinpoint early cultivation and sedentary settlements.

\section{Interpreted land use history of the study sites}

According to our results, land use in Tjärn and in Svensbyn can be traced back almost to the time when the sampled sites emerged from the sea, i.e. around $100 \mathrm{BC}$ and $\mathrm{AD} 600$, respectively. At Tjärn, lake-shore vegetation, including deciduous trees, grasses, sedges and ferns, initially dominated the swamp wood. Due to land uplift, the area surrounding the swamp wood soon became suitable for human land use. Sporadic Secale and Cerealia-type pollen are recorded from $\mathrm{AD}$ 950-1020 and around 1170 there were permanent cultivated fields as shown by continuous finds of Hordeum-type and Secale pollen, and later Triticum-type pollen, and grass meadows were established in the vicinity of the swamp wood. At this time anthropochores, apophytes and charcoal finds start increasing, indicating the use of fire to clear and manage the land (Wallin and Segerström 1994). Most certainly, hemp was retted in the wet areas of the swamp as indicated by high percentages of Cannabis-type pollen (Larsson and Lagerås 2015), and somewhere in the neighbourhood flax was cultivated from 1480 onwards, as shown by records of Linum usitatissimum pollen. Furthermore, archaeological excavations of a sedentary farm site $8 \mathrm{~km}$ east of Tjärn, on the north riverside of the Skelleftälven, indicate that cultivation started here during the 13th century (Liedgren 2016).

Pinpointing the start of human land use and cereal cultivation in the Svensbyn area is much more difficult and exemplifies some of the typical problems in palynological research, estimating the sedimentation rate and identification of cereal pollen types. Aquatic vegetation including Myriophyllum and Potamogeton dominated the site shortly after the land emerged from the sea around $200 \mathrm{BC}$. The close proximity to the sea is also indicated by records of Hippophä̈ (sea-buckthorn). There are already subtle signs of human land use during the 1st century $\mathrm{AD}$ as indicated by an increase of both apophytes and anthropochores. Substantial 


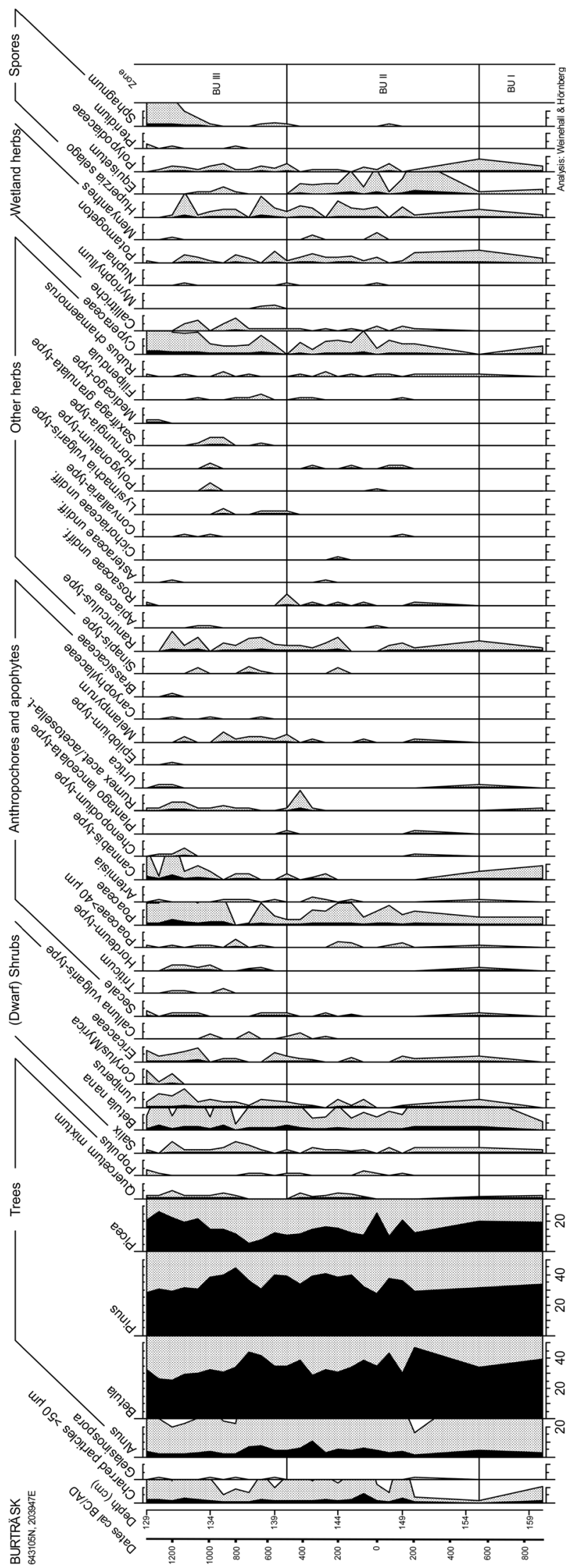

4Fig. 7 Pollen percentage diagram for Burträsk divided into three pollen assemblage zones. From left to right: interpolated calibrated ages $(\mathrm{BC} / \mathrm{AD})$; depths $(\mathrm{cm})$; microscopic charred particles $(>50 \mu \mathrm{m})$; pollen and spore types as percentages (black shading) and at $\times 10$ magnification (grey shading). The solid lines mark zones: $B U I$ preagrarian conditions, $B U$ II shifting cultivation, $B U$ III permanent cultivation. Herb pollen types only recorded once and at one level have been omitted

amounts of charcoal and pollen from Artemisia, Chenopodiaceae, Rumex and Urtica are recorded during this time, and around $\mathrm{AD} 125$ the first Hordeum-type pollen is recorded, indicating shifting cultivation of a similar type to that found in Tjärn and along the Swedish coast of the Gulf of Bothnia (Wallin 1996) and western Finland (Wallin and Segerström 1994). Hence, the pollen assemblages, including anthropochores, indicate that cultivation may have been practised around the Svensbyn site during the 1st millennium AD. The source area of pollen, as defined by Sugita (1994), for 5 ha lakes can vary between 900 and 1,100 m (Hjelle and Sugita 2012), but cereal pollen grains have a very restricted dispersal capacity (Vuorela 1973) so the fields were probably rather close to the site. Furthermore, the sea engulfed the sampling site to the north as well as to the east where Svensbyn village is located today and most of the Svensbyn area was still submerged below sea level around $\mathrm{AD} 800$; the first farms in this village were probably established on higher ground to the south (Roeck Hansen 2002).

However, because of the close proximity to the sea and because no pollen of Secale or Triticum-types were recorded at this time, we cannot rule out the possibility that the recorded Hordeum-type pollen actually derives from Elymus arenarius, which is a wild grass that is typical of sea shores and has pollen grains that are very similar in size and shape to Hordeum (Hörnberg et al. 2014). The closeness to eroding sandy shores is further strengthened by the presence of Hippophä pollen around AD 440 and 1010 (Fig. 5). Between 990 and 1390, depending on which agedepth model is used, we identified Secale pollen and during the following time period we also recorded Hordeum-type pollen and an increase in grasses, Cannabis and Rumex indicating intensified land use close to this site, including retting of hemp in the lake. The resolution is, however, poor towards the top of the diagram and there are no indications of permanent fields. It is likely that the land surrounding the sampling site was used for grazing, fodder collection and possibly for cultivation from time to time (Engelmark 1976; Wallin and Segerström 1994; Wallin 1996). During this time cattle, sheep and goats were the main livestock of the historical farms in northernmost Sweden, and they were herded in the forests surrounding the villages during the snow-free period. This foraging was carefully regulated by the villages (Isaksson 1967). 
Table 3 Major changes in vegetation composition in the coastal study sites Tjärn (Fig. 4) and Svensbyn (Fig. 5). Dates (BC/AD) are calibrated 'best' weighted averages of the ages from the age-depth model. Ages within brackets show the calibrated age range $(2 \sigma)$

PAZ: $\mathrm{BC} / \mathrm{AD} \quad \begin{aligned} & \text { Depth Zone description } \\ & (\mathrm{cm})\end{aligned}$

TJ I:

AD 300-950

TJ II:

AD $950-1170$

TJ III:

AD 1170-1780

SV IIa:

125 BC-AD 1060

$(125 \mathrm{BC}-\mathrm{AD} 1340)^{*}$

SV IIb:

AD $1060-1180$

(AD 1340-1850)*
65-56 Trees: decrease in Alnus 8-2 \% and Pinus 25-18\%; increase in Betula 12-22\% and Picea 24-33\%; Populus intermittent $<1 \%$

Shrubs and dwarf shrubs: decrease in B. nana $15-6 \%$; Myrica, Rosaceae and Salix $<1 \%$; Juniperus, Ericaceae and Calluna sporadic

Anthropochores and apophytes: Poaceae continuous 2-5\%; Artemisia intermittent $<1 \%$; Cannabis-type, Plantago-type, Chenopodiaceae, Urtica and Brassicaceae sporadic

Other herbs: Cyperaceae continuous 2-5\%; Filipendula, Galium-, Ranunculus- and Solanum dulcamara-type intermittent $<1 \%$

Charcoal continuous $<1 \%$

56-53 Trees: Alnus $4 \%$; decrease in Betula 17-15\% and Picea 31-23\%; Pinus 19-22 \%; Populus sporadic $<1 \%$

Shrubs and dwarf shrubs: B. nana 10-14 \%; Juniperus, Salix and Calluna continuous $<1 \%$; Myrica recurrent $<1 \%$

Anthropochores and apophytes: Secale at $56 \mathrm{~cm}$ (AD 890-1040, 2 $\sigma$ ) and Cerealia undiff. at $55 \mathrm{~cm}$ (AD 970-1100, 2 $\sigma$ ); Poaceae continuous 3-5\%; Artemisia continuous $<1 \%$; Rumex recurrently $<1 \%$; Melampyrum and Poaceae $>40 \mu \mathrm{m}$ sporadic

Other herbs: Cyperaceae continuous 2-4\%; Filipendula continuous $<1 \%$; Apiaceae and Rosaceae recurrent $<1 \%$; Anagallis-type and Ranunculus-type sporadic

Charcoal 1-2\%

53-31 Trees: Alnus 3-6 \%; decrease in Betula 18-8 \%; Picea 23-8 \% and Pinus 24-15\%; Populus sporadic

Shrubs and dwarf shrubs: decrease in B. nana 11-3\% and Salix 3-1\%; increase in Juniperus $>2 \%$; Ericaceae and Calluna recurrently $<1 \%$

Anthropochores and apophytes: Hordeum-type, Secale, Triticum and Cerealia undiff. occur from

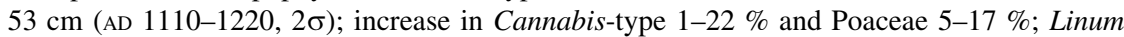
usitatissimum recurrent from $45 \mathrm{~cm}$ (AD 1420-1540, 2 $\sigma$ ); Rumex continuous $<3 \%$; Poaceae $>40 \mu \mathrm{m}$; Urtica, Artemisia and Brassicaceae continuous $<1 \%$; Chenopodiaceae, Melampyrum and Caryophyllaceae intermittent $<1 \%$; Plantago-type sporadic

Other herbs: Cyperaceae continuous 3-8 \%; Apiaceae, Rosaceae and Ranunculus-type continuous $<2 \%$; Asteraceae, Filipendula and recurrently $<2 \%$; Alchemilla, Medicago and Spergula sporadic

Charcoal $1-3 \%$

109-81 Trees: decrease in Alnus 12-3\% and Betula 50-25 \%; Pinus 20-30 \%; increase in Picea 10-43\%; Populus sporadic

Shrubs and dwarf shrubs: Ericaceae continuous $<1 \%$ from $94 \mathrm{~cm}$; Salix, Juniperus and Corylus recurrently $<1 \%$; Hippophae and Calluna sporadic

Anthropochores and apophytes: Hordeum-type intermittent from $105 \mathrm{~cm}(* *, \mathrm{AD} 10-210,2 \sigma)$, decrease in Poaceae 12-1 \%; Poaceae $>40 \mu \mathrm{m}$ continuous $<1 \%$; Artemisia, Cannabis-type, Rumex, Urtica recurrent $<1 \%$; Caryophyllaceae, Epilobium, Chenopodiaceae sporadic

Other herbs: Cyperaceae continuous $<3 \%$; Ranunculus, Filipendula and Rosaceae recurrently $<1 \%$

Charcoal: Recurrently $<1 \%$

81-70 Trees: decrease in Alnus 3-1 \% and Betula 25-17\%; Pinus 25-30 \%; Picea 35-28 \%

Shrubs and dwarf shrubs: Salix, Juniperus, Corylus, Ericaceae and Calluna sporadic

Anthropochores and apophytes: Secale at $81 \mathrm{~cm}$ (AD 990-1110, AD 1270-1390*, 2б); Hordeum-type sporadic; Poaceae 1-5\%; Cannabis-type 0-5\%; Artemisia, Rumex, Chenopodiaceae and Urticatype sporadic

Other herbs: Cyperaceae 1-2\%

Charcoal sporadic $<1 \%$

\footnotetext{
* Alternative age-depth model for Svensbyn (Fig. 3)

** Correlates to the first Hordeum-type pollen recorded in Svensbyn (Fig. 5)
} 
Table 4 Major changes in vegetation composition in the inland study sites Norsjö (Fig. 6) and Burträsk (Fig. 7). Dates (BC/AD) are calibrated 'best' weighted averages of the ages from the age-depth model. Ages within brackets show the calibrated age range $(2 \sigma)$

\begin{tabular}{|c|c|}
\hline PAZ: $\mathrm{BC} / \mathrm{AD}$ & $\begin{array}{l}\text { Depth Zone description } \\
(\mathrm{cm})\end{array}$ \\
\hline
\end{tabular}

NO I:

40 BC-AD 500

NO II: AD 500-1490

NO III:

AD $1490-1840$

BU I:

$900-560$ вС

BU II:

$560 \mathrm{BC}-\mathrm{AD} 480$

BU III:

AD 480-1210
70-41 Trees: Alnus 1-2 \%; Betula 21-35\%; Pinus and Picea 30-12 \% fluctuating; Populus sporadic

Shrubs andd dwarf shrubs: Ericaceae, B. nana and Calluna continuous $<7 \%$; Salix and Juniperus intermittent $<1 \%$

Anthropochores and apophytes: Poaceae, Cannabis-type, Melampyrum and Urtica-type recurrent $<1 \%$; Rumex sporadic

Other herbs: Rosaceae recurrent $<1 \%$; Cyperaceae, Ranunculus and Convallaria intermittent

Charcoal: recurrently $0-1 \%$

41-18 Trees: Alnus <2 \%; Betula initial increase to $66 \%(37 \mathrm{~cm})$ then decrease to $22 \%$; Pinus fluctuating 6-33\%; Picea fluctuating $8-26 \%$

Shrubs and dwarf shrubs: Ericaceae increase to $33 \%(25 \mathrm{~cm}$, AD 1030-1160, 2б) then decrease to $8 \%$; B. nana, Corylus and Calluna continuous $<5 \%$; Salix and Juniperus intermittent $<1 \%$

Anthropochores and apophytes: Secale at 41 and $33 \mathrm{~cm}$ (AD 410-540 and AD 690-840, 2б); Hordeum-type at

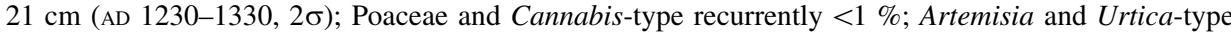
intermittent $<1 \%$; Chenopodiaceae, Rumex and Brassicaceae sporadic

Other herbs: Ranunculus, Rosaceae and Cyperaceae intermittent $<1 \%$

Charcoal: increase to $21 \%$ at $32 \mathrm{~cm}$ (AD 720-880, 2 $\sigma$ ) then continuous between 1 and $3 \%$ (Gelasinospora spores also peak at $32 \mathrm{~cm}$ )

18-10 Trees: Alnus <1 \%; Betula increase 14-23\%; Pinus increase 15-36 \%; Picea decrease 12-8 \%

Shrubs and dwarf shrubs: decrease in Ericaceae 13-3\%; Salix, Juniperus, B. nana and Calluna intermittent $1-3 \%$

Anthropochores and apophytes: Secale, Triticum and Hordeum-type occur <1\% from $18 \mathrm{~cm}$ (AD 1420-1600, $2 \sigma$ ); Poaceae and Rumex 2-7 \%; Poaceae $>40 \mu \mathrm{m}$ and Melampyrum continuous $<2 \%$; Artemisia, Cannabistype, Chenopodiaceae, Urtica, Cichoriaceae undiff., Caryophyllaceae and Epilobium intermittent $<1 \%$

Other herbs: Ranunculus, Apiaceae and Cyperaceae intermittent $<3 \%$

Charcoal: $1-2 \%$

160-155 Trees: Alnus $3 \%$; Betula $40 \%$; Pinus $30 \%$; Picea $20 \%$

Shrubs and dwarf shrubs: Salix and B. nana $<1 \%$

Anthropochores and apophytes: Poaceae, Cannabis-type and Rumex $<1 \%$

Other herbs: Ranunculus and Cyperaceae $<1 \%$

Charcoal: $1 \%$

155-140 Trees: Alnus 1-10 \%; Betula 47-38 \%; Pinus 36-40 \%; Picea 25-12\%; Populus recurrently <1\%

Shrubs and dwarf shrubs: B. nana, Salix and Juniperus continuous 1-2 \%; Ericaceae and Calluna intermittent

Anthropochores and apophytes: Secale (155, 145 and $143 \mathrm{~cm}, 630-490$ BC, AD 80-200 and AD 210-330, 2 $\sigma$ ); Poaceae continuous 1-2\%; Poaceae $>40 \mu \mathrm{m}$ and Melampyrum intermittent $<1 \%$; Cannabis-type,

Chenopodiaceae, Plantago lanceolata-type and Rumex sporadic

Other herbs: Cyperaceae continuous $1 \%$; Ranunculus recurrent $<1 \%$

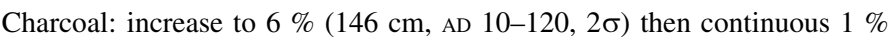

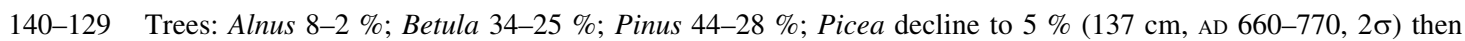
increase to $20 \%$

Shrubs and dwarf shrubs: B. nana 1-3\%; Salix and Juniperus continuous $<1 \%$; Corylus, Ericaceae and Calluna intermittent $<1 \%$

Anthropochores and apophytes: Secale, Hordeum-type and Triticum recurrently (from $140 \mathrm{~cm}, \mathrm{AD}$ 410-550, 2 $\sigma$ ); Poaceae, Poaceae $>40 \mu \mathrm{m}$, Cannabis-type, Rumex and Melampyrum recurrently $<1-2 \%$; Caryophyllaceae intermittent $<1 \%$; Chenopodiaceae, Urtica, Epilobium and Brassicaceae sporadic

Other herbs: Cyperaceae continuous $<1-2 \%$, Ranunculus, Saxifraga granulata-type and Filipendula recurrently Charcoal: continuous $<1-3 \%$ (Gelasinospora intermittent) 


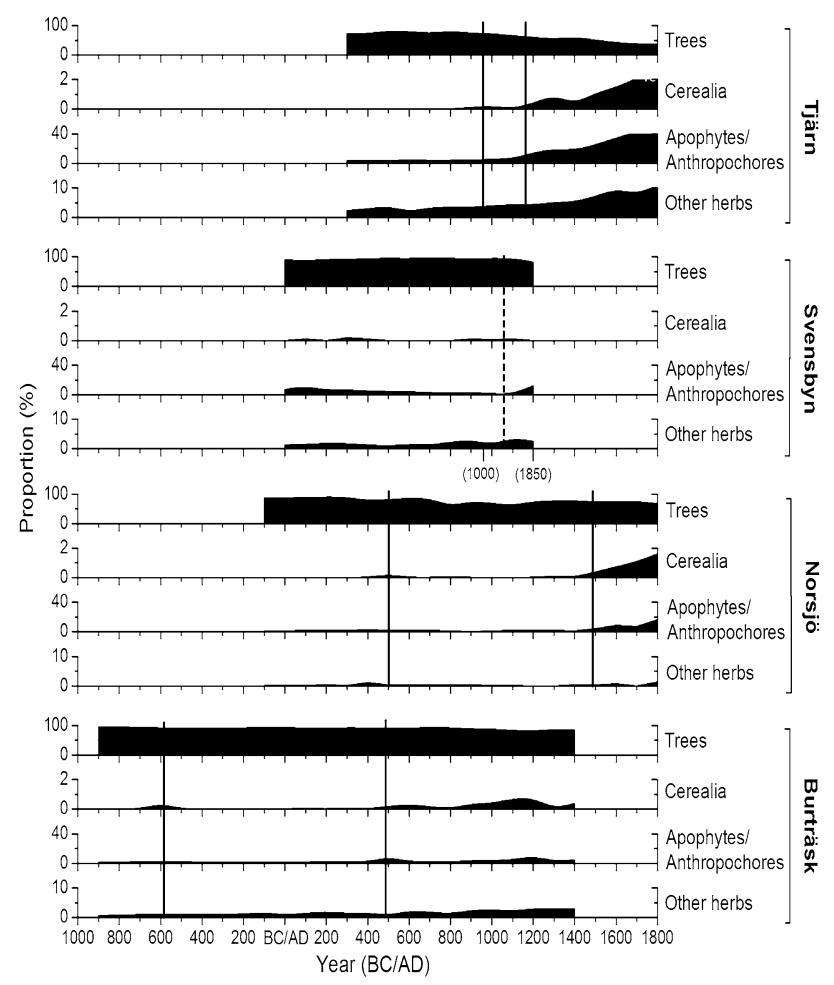

Fig. 8 Composite pollen diagram of trees (arboreal pollen), Cerealia, anthropochores and apophytes, and other herbs for Tjärn, Svensbyn, Norsjö and Burträsk. Lines correspond to pollen assemblage zones in Figs. 4, 5, 6 and 7. Data presented in percentages. Calibrated ages from alternative age-depth model for Svensbyn within brackets

At the two inland localities, Norsjö and Burträsk, landuse history follows a similar pattern as in Tjärn and Svensbyn but is asynchronous. The presence of many apophytes including Artemisia, Cannabis, Melampyrum and Urtica indicates human land use at both sites far back in time. Scattered occurrences of Secale pollen appear as early as 560 BC in Burträsk, together with Hordeum-type pollen, and about 1,000 years later in Norsjö. Based on the archaeological records, both the Norsjö and the Burträsk areas have been occupied for a long time. Around the 1st century $\mathrm{BC}$ in Burträsk and the 9th century $\mathrm{AD}$ in Norsjö, forest fires became more common, possibly indicating intensified land use including the use of fire for clearing and managing the areas surrounding the sample sites. This interpretation is further strengthened by a simultaneous decrease in Betula pollen at Burträsk and in tree pollen at Norsjö. The establishment of permanent cultivation occurs around AD 480 in Burträsk and ca. 1490 in Norsjö. This is clearly illustrated at both sites by continuous finds of the cereal pollen types Hordeum, Secale and Triticum, accompanied by a strong increase in apophytes and a herbaceous flora. Accordingly, both shifting cultivation and permanent cultivation were established about 1,000 years earlier in Burträsk than in Norsjö.

\section{Pollen data sets, land use and the start of permanent cultivation}

The criteria for zonation of the pollen diagrams used in this study rely on the presence or absence of cereal pollen, pollen from certain apophytes and other herbs, and to some extent proportions of arboreal pollen. This approach has been applied previously and has proven useful to identify periods with prehistoric land use in boreal ecosystems (Vuorela 2007). In pre-agrarian times in northern Fennoscandia the landscape was characterised by vast forests dominated by Pinus sylvestris (Scots pine), Picea abies (Norway spruce) and Betula pubescens (downy birch) with very low abundances of grasses and herbs. This condition is well reflected in the pollen data from Tjärn, Norsjö and Burträsk (Figs. 4, 6 and 7). Still, people had been present in this region for millennia, but land use activities such as hunting, fishing, or gathering of resources are difficult to detect in the pollen data (Behre 1986; Aronsson 1991; Hicks 1993). However, in Tjärn, Norsjö and Burträsk a change in vegetation composition, most certainly caused by a changed or increased land use including shifting cultivation, is discernible in the pollen data sets as the emergence of sporadic, small records of cereal pollen (notably Secale), apophytes (pollen types such as Cannabis, Chenopodium, Epilobium and Urtica) and fluctuating or increased levels of charred particles (Hicks 1988; Hörnberg et al. 2015). Single occurrences of cereal pollen recorded at one site alone cannot verify early shifting cultivation but together with a specific set of pollen types and changes in the amount of charred particles they provide good indications of early small-scale farming. This change occurred between $550 \mathrm{BC}$ and $\mathrm{AD}$ 950, first in Burträsk and last in Tjärn. In Svensbyn, a similar change in vegetation composition could not be detected. Possibly, the land around this site was used soon after it emerged from the sea at ca. $200 \mathrm{BC}$ according to calculations based on data derived from Lindén et al. (2006). When permanent settlements were established near the sampling sites in Tjärn, Norsjö and Burträsk, or in the local areas, even more pronounced vegetation changes occurred and these are indicated by the pollen data set including continuous finds of cereal pollen (Secale and Triticum) and increased proportions of apophytes (notably grasses and Brassicaceae, Cannabis, Caryophyllaceae, Chenopodium, Rumex and Urtica) and herbs (Apiaceae and Asteraceae).

One aim of this study was to pinpoint the beginning of permanent cereal cultivation at each site. To do this we carefully selected the sites on the basis of archaeological records, old maps and past/present elevation above sea level. Furthermore, the pollen data were derived from small archives $<100 \mathrm{~m}$ in diameter. Consequently, the basis for dating the start of shifting cultivation and permanent 
cultivation at each place was good. The pollen data from Burträsk, however, were obtained from a small lake of 0.27 ha, whereas the other pollen data sets were collected from peat deposits. This means that this pollen data set represents a somewhat larger extra-local pollen catchment area than those from Tjärn, Svensbyn and Norsjö. Nonetheless, in a region that previously has been regarded as having had no farming before medieval times, all four data sets provide important information on farming history and the earliest development of agrarian settlements in northern Sweden.

\section{New insights into early cereal cultivation in northernmost Fennoscandia}

From what is known about land use history in northern Fennoscandia, the development of an agricultural economy first occurred along the coasts of the North Atlantic and the Gulf of Bothnia (Baudou 1982; Ramqvist 1983; Sundström 1984; Johansen and Vorren 1986; Liedgren 1992; Wallerström 1995; Taavitsainen et al. 1998). This suggestion is supported by a series of pollen studies carried out during the last four decades and reviewed in Josefsson et al. (2014), and is not contested here, but in this study we seek to extend this knowledge. The extent to which areas in northern Europe are suitable for cultivation depends on a number of ecological and physio-geographic factors, including the length of the vegetation growing period, biota, soil properties, climate, hydrology and glacial isostatic adjustment. Naturally, the fertile soils along the coast and major rivers were easy to reach and therefore were among the first to be used for farming. As a result, much research into cultivation history has been carried out in such areas (Josefsson et al. 2014), and for northernmost Sweden it has been proposed by Wallerström (1995) that permanent settlements with cereal growing were established along the coast in two different waves: the first from Finland in the east, at latest during the 13th century, and a second wave from the south that started during the 14th century which was initiated by the Swedish king. The idea of colonization from the south is solely based on historical records and has gained support from many scholars over a long period (Wallerström 1995, p. 47 ff). In this study, we find support for a more complicated origin for cereal growing and permanent farms in northernmost Sweden that involved shifting cultivation, access to waterways and communication, and shore displacement following land uplift.

In northernmost Sweden, there are a large number of sites with cereal pollen records that are scattered over a vast geographical area which could indicate small-scale shifting cultivation (Josefsson et al. 2014). This form of land use most probably occurred along the coast for a long time, probably from 850 BC (Tolonen 1972; Engelmark 1976), and at least from $400 \mathrm{BC}$ (Wallin 1996) until AD 1200 (Segerström 1990a, b, 1995). Interestingly, the same pattern is found inland, where long distance dispersal of cereal pollen would have been very restricted in the past due to the densely wooded landscape (Segerström 1982, 1990a; Giesecke 2005; van der Linden et al. 2008; Josefsson 2009; Staland et al. 2011; Hörnberg et al. 2015). These studies contribute to new perspectives on the cultivation history of northernmost Sweden in general, and on cultivation practices among inland hunter-herders in northern Fennoscandia in particular (Bergman and Hörnberg 2015).

In contrast to the general idea that sedentary permanent cultivation in northernmost Sweden first emerged along the coast in the 13th century, the results presented here show that permanent cultivation was established much earlier in the interior, during the 5th century $\mathrm{AD}$ in Burträsk, than in the coastal area during the 12th century AD in Tjärn. The introduction of permanent agriculture in Burträsk actually precedes many previous indications of early cereal cultivation in the northernmost coastal areas of both Sweden and Finland (Segerström 1990b; Hicks 1992; Wallin and Segerström 1994; Wallin 1996; Hörnberg et al. 2014). The establishment of permanent farms involved a stable but more complex lifestyle compared to subsistence relying on shifting cultivation. These farms invested labour in permanent fields which had to be manured every year. The manure came mostly from cattle which had to be kept in sheds during the long winter, and to support this livestock during the winter a large amount of fodder had to be collected from natural meadows and fens. Our result has two important implications: the establishment of a permanent farm around $\mathrm{AD} 480$ in Burträsk located $30 \mathrm{~km}$ inland from the coast provides an earlier date for the start of cereal cultivation in this part of Sweden, and it shows that farming settlements were not necessarily established directly on the coast or along major rivers. Instead, other factors such as access to waterways and communication routes and also shore displacement following land uplift must be considered; Segerström (1990b) suggested that continuous land use including cereal cultivation may have started as early as AD 700-1000 at Heden, about $20 \mathrm{~km}$ inland from the coast at Luleå (Fig. 1).

Obviously, suitable land for cultivation could be found far from the coast and major rivers in both northern Finland (Grönlund et al. 1992; Vuorela 1997) and northern Norway (Høeg 1972, 2000). The present study supports these results which contribute to our understanding of past land use. However, some studies probably indicate small-scale shifting cultivation because the interpretations are mainly based on single or scattered occurrences of Cerealia-type pollen. Although land suitable for cultivation was abundant, it is plausible that the earliest start of permanent 
farming relied on close contact between the settlements and reliable transport routes. This is exemplified by a comparison of the two inland areas, Norsjö and Burträsk. Norsjö is situated well above the highest sea level and at a distance of ca. $15 \mathrm{~km}$ from the Skellefteälven, which is the closest major river. A permanent settlement with cereal cultivation is presumed to have been established there ca. $\mathrm{AD}$ 1400. On the other hand, the Burträsk site has, since it emerged from the sea around 6,000 years ago, remained connected to the sea via the Bureälven and a series of small lakes, facilitating close contact with the coastal communities, including trade and transfer of people and knowledge. Clearly, isostatic land uplift plays an important part in identifying areas that may have been used by humans in the past (Bergman et al. 2003; Möller et al. 2013). At the start of the medieval period the sea level was about $8 \mathrm{~m}$ higher than now, and at the time that permanent cultivation started in Burträsk it was ca. $12 \mathrm{~m}$ above present sea level, according to calculations based on data from Lindén et al. (2006). This means that areas with suitable soils for farming, like Burträsk, were much closer to the coast when they were settled. Accordingly, in regions with gentle slopes, lowland areas, an undulating coastline and river outlets, the earliest sedentary settlements may actually be found some distance from the present coastline as a result of the isostatic land uplift. A similar reasoning has been put forward by Wallin and Segerström (1994) who pointed out the significance of coastline displacement due to land uplift for explaining the rapid relocation of Iron Age settlement in coastal areas in western Finland.

\section{Concluding remarks}

Analysing and resolving the start of early cereal cultivation in northernmost Fennoscandia requires an interdisciplinary approach. Historical maps combined with field studies that take isostatic land uplift into account aid our search for possible sites with early settlements. The archaeological record gives little evidence of early permanent farms because their remains have been erased by more recent land use practices and building. The most typical feature of such farms in other areas further to the south of our study area in northern Sweden is the presence of barrow mounds. However, these are totally absent from sedentary settlements in northernmost Sweden, with the exception of two mounds in Sangis and Espinära (Ramqvist and Hörnberg 2015). Pollen, including careful identification of cereal pollen types and apophytes, provides information about past land use including periods of cereal cultivation from continuous finds of cereal pollen grains. By using radiocarbon dating, the beginning of permanent cultivation may be pinpointed in time. Following this approach we present evidence of permanent cultivation from ca. $\mathrm{AD} 480$ and onwards at an inland settlement located at the 64th parallel north in northern Sweden, and from ca. AD 1170 at a coastal settlement. Our results indicate that small-scale shifting cultivating occurred irregularly in this part of northern Fennoscandia ca. 500 BC-AD 1500 as shown by sporadic, small records of cereal pollen (notably Secale), apophytes (pollen types such as Cannabis, Chenopodium, Epilobium and Urtica) and fluctuating or increased levels of charred particles. A transition to an intensified land use including permanent farms occurred ca. AD 500-1500 as shown by continuous finds of cereal pollen types (Secale and Triticum) and increased proportions of apophytes (notably grasses and Brassicaceae, Cannabis, Caryophyllaceae, Chenopodium, Rumex and Urtica) and herbs. Important factors when choosing study sites in order to pinpoint early cultivation and sedentary settlements include access to waterways and communication routes in all regions, and shore displacement following land uplift in areas located below the highest sea shoreline. We believe that these results have implications for attempts to interpret and resolve the early cultivation history in other parts of northern Fennoscandia.

Acknowledgments We wish to thank Anna Weinehall for assisting with the pollen analysis and two anonymous reviewers for very useful and much appreciated comments on earlier versions of the manuscript. The English has been corrected by Sees-editing Ltd, UK. This study is a part of the research programme "Recalling the Past" financed by the Bank of Sweden Tercentenary Foundation Grant No. M11-0361:1.

Open Access This article is distributed under the terms of the Creative Commons Attribution 4.0 International License (http://crea tivecommons.org/licenses/by/4.0/), which permits unrestricted use, distribution, and reproduction in any medium, provided you give appropriate credit to the original author(s) and the source, provide a link to the Creative Commons license, and indicate if changes were made.

\section{References}

Ågren J, Svensson R (2007) Postglacial land uplift model and system definition for the new Swedish height system RH 2000. LMVrapport 2007:4. Lantmäteriverket, Gävle

Aronsson KA (1991) Forest reindeer herding $\mathrm{AD}$ 1-1800: an archaeological and palaeoecological study in northern Sweden. (Archaeology and Environment 10) Department of Archaeology University of Umeå, Umeå

Baudou E (1982) Det förhistoriska jordbruket i Norrland: bakgrunden i det arkeologiska fyndmaterialet [Prehistoric agriculture in Northern Sweden: background of the archaeological records]. In: Sjøvold T (ed) Introduksjonen av jordbruk i Norden: foredrag holdt ved fellesnordisk symposium i Oslo April 1980. Universitetsforlaget, Oslo, pp 163-171

Behre KE (ed) (1986) Anthropogenic indicators in pollen diagrams. Balkema, Rotterdam

Behre KE (2007) Evidence for Mesolithic agriculture in and around central Europe? Veget Hist Archaeobot 16:203-219 
Bergman I, Hörnberg G (2015) Early cereal cultivation at Sámi settlements: challenging the hunter-herder paradigm? Arct Anthropol 52:57-66

Bergman I, Påsse T, Olofsson A, Zackrisson O, Hörnberg G, Hellberg E, Bohlin E (2003) Isostatic land uplift and Mesolithic landscapes: lake-tilting, a key to the discovery of Mesolithic sites in the interior of Northern Sweden. J Archaeol Sci $30: 1,451-1,458$

Blaauw M (2010) Methods and code for 'classical' age-modelling of radiocarbon sequences. Quat Geochronol 5:512-518

Broadbent N (1982) Skelleftebygdens historia 3. Den förhistoriska utvecklingen under 7000 år [The history of the Skellefte area 3. The prehistoric development during 7,000 years]. Skellefteå kommun, Skellefteå

Engelmark R (1976) The vegetational history of the Umeå area during the past 4,000 years. In: Engelmark R (ed) Palaeo-ecological investigations in coastal Västerbotten, N. Sweden. (Early Norrland 9) Kungl. Vitterhets-, historie- och antikvitetsakad, Stockholm, pp 73-111

Giesecke T (2005) Holocene forest development in the central Scandes Mountains, Sweden. Veget Hist Archaeobot 14:133-147

Grimm EC (1991) TILIA v. 2.0.b.4. Illinois State Museum, Research and Collections Center, Springfield

Grimm EC (2004) TILIA GRAPH v. 2.0.2. Illinois State Museum, Research and Collections Center, Springfield

Grönlund E, Kivinen L, Simola H (1992) Pollen analytical evidence for Bronze-age cultivation in eastern Finland. Laborativ Arkeol 6:37-48

Hicks S (1988) The representation of different farming practices in pollen diagrams from northern Finland. In: Birks HH, Birks HJB, Kaland PE, Moe D (eds) The cultural landscape: past, present and future. Cambridge University Press, Cambridge, pp 189-207

Hicks S (1992) Modern pollen deposition and its use in interpreting the occupation history of the island Hailuoto, Finland. Veget Hist Archaeobot 1:75-86

Hicks S (1993) Pollen evidence of localized impact on the vegetation of northernmost Finland by hunter-gatherers. Veget Hist Archaeobot 2:137-144

Hjelle KL, Sugita S (2012) Estimating pollen productivity and relevant source area of pollen using lake sediments in Norway: how does lake size variation affect the estimates? Holocene 22:313-324

Høeg HI (1972) En pollenanalytisk undersøkelse i Skaitidalen, Saltdal kommune, Nordland [A pollenanalytical survey in Skaiti valley, Saltdal municipality, Nordland]. Masters thesis, University of Oslo, Olso

Høeg HI (2000) Pollenanalytiske undersøkelser i Finnmark, Nord Norge [Pollen analytical surveys in Finnmark, northern Norway]. AmS-Varia 37:53-97

Hörnberg G, Josefsson T, Liedgren L (2014) Revealing the cultivation history of northernmost Sweden: evidence from pollen records. Holocene 24:318-326

Hörnberg G, Josefsson T, Bergman I, Liedgren L, Östlund L (2015) Indications of shifting cultivation west of the Lapland border: multifaceted land use in northernmost Sweden since AD 800. Holocene 25:989-1,001

Isaksson O (1967) Bystämma och bystadga: organisationsformer i övre Norrlands kustbyar: om samspelet mellan lokal tradition och central påverkan [Village assembly and statute: forms of organisation in coast villages of northernmost Sweden: the interaction between local tradition and central influence]. (Kungl. Skytteanska samfundets handlingar 5) Almkvist och Wiksell, Uppsala

Jensen C, Elverland E (2009) Vegetationshistorie og bosetningsfaser på Melkøya og Meland gjennom de siste ca. 10.000 år
[Vegetation history and settlement phases at Melkøya and Meland throughout the last ca. 10,000 years]. In: Hesjedal A, Ramstad M, Niemi AR (eds) Undersøkelsene på Melkøya: Melkøyaprosjektet - kulturhistoriske registreringer og utgravninger 2001 og 2002. (Tromura 36) Troms $\varnothing$ museum, Universitetsmuseet, Troms $\varnothing$, pp 438-461

Johansen OS, Vorren KD (1986) The prehistoric expansion of farming into "arctic" Norway: a chronology based on 14C dating. Radiocarbon 28:739-747

Josefsson T (2009) Pristine forest landscapes as ecological references: human land use and ecosystem change in boreal Fennoscandia. Doctoral Dissertation, Department of Forest Ecology and Management Swedish University of Agricultural Sciences, Umeå

Josefsson T, Ramqvist P, Hörnberg G (2014) The history of early cereal cultivation in northernmost Fennoscandia as indicated by palynological research. Veget Hist Archaeobot 23:821840

Lahtinen M, Rowley-Conwy P (2013) Early farming in Finland: was there cultivation before the Iron Age $(500 \mathrm{BC})$ ? Eu J Archaeol 16:660-684

Larsson M, Lagerås P (2015) New evidence on the introduction, cultivation and processing of hemp (Cannabis sativa L.) in southern Sweden. Environ Archaeol 20:111-119

Liedgren L (1992) Hus och gård i Hälsingland: en studie av agrar bebyggelse och bebyggelseutveckling i norra Hälsingland Kr.f.600 e.Kr. [House and farm in Hälsingland: a study of agrarian settlement and settlement development in northern Hälsingland AD 1-600]. (Studia archaeologica Universitatis Umensis 2) Doctoral Dissertation, Umeå University, Umeå

Liedgren L (2016) Ön i Degerbyn: en medeltida gårdsplats i Skellefteå [The island in Degerbyn: a medieval farmstead in Skellefteå]. Arkeol Norr 16:141-168

Lindén M, Möller P, Björck S, Sandgren P (2006) Holocene shore displacement and deglaciation chronology in Norrbotten, Sweden. Boreas 35:1-22

Lindqvist A-K, Granholm N (2016) Stolpbygda hus vid Umeålvens mynning. Den yngre bronsåldern i ny skepnad [Post-built houses at the Ume river outlet. New insights on the early Bronze Age]. Arkeol Norr 15:37-62

Möller P, Östlund O, Barnekow L, Sandgren P, Palmbo F, Willerslev E (2013) Living at the margin of the retreating Fennoscandian ice sheet: the early Mesolithic sites at Aareavaara, northernmost Sweden. Holocene 23:104-116

Moore PD, Webb JA, Collinson ME (1991) Pollen analysis, 2nd edn. Blackwell, Oxford

Nilsson M, Klarqvist M, Bohlin E, Possnert G (2001) Variation in C-14 age of macrofossils and different fractions of minute peat samples dated by AMS. Holocene 11:579-586

Nordlander J (1905) 1543 Jordaboken af Västerbotten: till Västerbottens äldre kulturhistoria [The Västerbotten land register of 1543: the old cultural history of Västerbotten]. Norrl Saml 6:273-362

Philippsen B (2013) The freshwater reservoir effect in radiocarbon dating. Herit Sci 1:24

Ramqvist PH (1983) Gene: on the origin, function and development of sedentary Iron Age settlement in northern Sweden. (Archaeology and environment 1) Doctoral Dissertation., Department of Archaeology Umeå University, Umeå

Ramqvist PH (2014) Om järnålderns och medeltidensbebyggelseetableringar i norr [The establishment of permanent settlements in northern Sweden during Iron Age and Medieval times]. Arkeol Norr 14:81-106

Ramqvist PH, Hörnberg G (2015) Burial mounds as settlement indicators: archaeological and palynological investigations at Sangis, northern Sweden. Fennos Archaeol 32:121-138 
R Development-Core-Team (2013) R: a Language and environment for statistical computing. R Foundation for Statistical Computing. Vienna, http://r-project.org

Reimer PJ, Bard E, Bayliss A et al (2013) IntCal13 and Marine13 radiocarbon age calibration curves 0-50,000 years cal BP. Radiocarbon 55:1,869-1,887

Roeck Hansen B (2002) Gårdsgärdor och tegskiftesåker: resursutnyttjande och kulturellt inflytande i det gamla landskapet Västerbotten [Fences and farms: resource use and cultural influence in the old landscape of Västerbotten]. (Kulturens frontlinjer 28) Umeå Universitet, Umeå

Segerström U (1982) Pollenanalytiska belägg för tidig medeltida odling vid Åsele tätort, Västerbotten [Pollen analytical evidence for cultivation during medieval times in Åsele, Västerbotten]. Umeå Universitet, Umeå

Segerström U (1990a) The natural Holocene vegetation development and the introduction of agriculture in northern Norrland, Sweden: studies of soil, peat and especially varved lake sediments. Doctoral Dissertation, Department of Ecological Botany Umeå University, Umeå

Segerström U (1990b) The post-glacial history of vegetation and agriculture in the Luleälv river valley. (Archaeology and Environment 7) Department of Archaeology, Umeå University, Umeå

Segerström U (1990c) The vegetational and agricultural history of a northern Swedish catchment studied by analysis of varved lake sediments. In: Segerström U (ed) The natural Holocene vegetation development and the introduction of agriculture in northern Norrland, Sweden: studies of soil, peat and especially varved lake sediments. Doctoral Dissertation, Department of Ecological Botany, Umeå University, Umeå, pp 1-33

Segerström U (1995) Vegetationshistoriska perspektiv på den fasta bosättningens uppkomst i Norrbottens kustland (inkl. Torneå) [The emergence of a permanent settlement in the coastal areas of Norrbotten (incl. Torneå) from a vegetation history point of view]. In: Wallerström T (ed) Norrbotten, Sverige och medeltiden: problem kring makt och bosättning i en europeisk periferi, del 2. (Studies in Medieval Archaeology 15) Almqvist \& Wiksell, Stockholm, pp 5-24

Sjögren P (2010) Pollenanalys [Pollen analysis]. In: Arntzen JE, Sommerseth I (eds) Den første gården i Nord-Norge: jordbruksbosettning fra bronsealder til jernalder på Kveøy. (Tromura 39) Troms $\varnothing$ museum, Universitetsmuseet, Troms $\emptyset$, pp 127-132

Sjögren P, Arntzen JE (2013) Agricultural practices in arctic Norway during the first millennium BC. Veget Hist Archaeobot 22:1-15

Sköld E, Lagerås P, Berglund B (2010) Temporal cultural landscape dynamics in a marginal upland area: agricultural expansions and contractions inferred from palynological evidence at Yttra Berg, southern Sweden. Veget Hist Archaeobot 19:121-136

Staland H, Salmonsson J, Hörnberg G (2011) A thousand years of human impact in the northern Scandinavian mountain range: long-lasting effects on forest lines and vegetation. Holocene 21:379-391

Sugita S (1994) Pollen representation of vegetation in Quaternary sediments: theory and method in patchy vegetation. J Ecol $82: 881-897$
Sundström H (1984) Bönder bryter bygd: studier i övre Norrlands äldre bebyggelsehistoria [Peasant pioneers: studies of the early settlement history of Sweden's far north], (Bothnica 4) Norrbottens Museum, Luleå

Taavitsainen J-P, Simola H, Grönlund E (1998) Cultivation history beyond the periphery: early agriculture in the North European boreal forest. J World Prehist 12:199-253

Tolonen K (1972) On the palaeo-ecology of the Hamptjärn basin, I Pollenstratigraphy. In: Tolonen K, Tolonen M (eds) Palaeoecological investigations in northern Sweden. (Early Norrland 1) The Central Office of National Antiquities, Stockholm, pp 42-52

Van der Linden M, Barke J, Vickery E, Charman DJ, Van Geel B (2008) Late Holocene human impact and climate change recorded in a North Swedish peat deposit. Palaeogeogr Palaeoclimatol Palaeoecol 258:1-27

Viklund K (2011) Early farming at Umeå in Västerbotten. J Swed Antiquarian Res 3:238-242

Vorren K-D, Alm T (1985) An attempt at synthesizing the Holocene biostratigraphy of a «type area » in northern Norway by means of recommended methods for zonation and comparison of biostratigraphical data. In: De Beaulieu JL, Pons A (eds) Paleohydrological changes in the temperate zone in the last 15,000 years. (Ecologia mediterranea 11) Centre Regional de Documentation Pedagogique, Marseille, pp 53-64

Vuorela I (1973) Relative pollen rain around cultivated fields. Acta Bot Fenn 102:1-27

Vuorela I (1997) Pihtiputaan Karvalampi paleoekologisen tutkimuksen kohteena [Palaeoecological investigation of Karvilampi lake, Pihtipudas]. Archive Report P34.4.119. Geological Survey of Finland

Vuorela I (2007) The settlement history of Central Finland based on pollen analysis and radiocarbon dates. Appendix 2. In: Taavitsainen JP, Vilkuna J, Forssell H (eds) Suojoki at Keuruu: a mid 14th-century site of the wilderness culture in the light of settlement historical processes in Central Finland. (Suomalaisen tiedeakatemian toimituksia Sarja Humaniora 346) Suomalainen Tiedeakatemia, Helsinki, pp 163-232

Wallerström T (1995) Norrbotten, Sverige och medeltiden: problem kring makt och bosättning $\mathrm{i}$ en europeisk periferi, del 1 [Norrbotten, Sweden and the Middle Ages: problems concerning power and settlement on a European periphery, part 1]. (Studies in Medieval Archaeology 15) Almqvist \& Wiksell, Stockholm

Wallin J-E (1996) Ekonomi och bebyggelsemönster vid övre Norrlands kustland under bronsålder och förromersk järnålder: resultat av pollenanalyser [Economy and settlement patterns in the coastland of northernmost Sweden during the Bronze Age and Pre-Roman Iron Age: pollenanalytical results]. Arkeol Norr 6(7):101-116

Wallin J-E, Segerström U (1994) Natural resources and agriculture during the Iron Age in Ostrobothnia, western Finland, investigated by pollen analysis. Veget Hist Archaeobot 3:89-105 